\title{
The Underpricing of Initial Public Offerings: Further Canadian Evidence
}

\author{
Maher Kooli, Jean-Marc Suret
}

Série Scientifique

Scientific Series

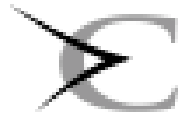

Montréal

Septembre 2001 


\section{CIRANO}

Le CIRANO est un organisme sans but lucratif constitué en vertu de la Loi des compagnies du Québec. Le financement de son infrastructure et de ses activités de recherche provient des cotisations de ses organisationsmembres, d'une subvention d'infrastructure du ministère de la Recherche, de la Science et de la Technologie, de même que des subventions et mandats obtenus par ses équipes de recherche.

CIRANO is a private non-profit organization incorporated under the Québec Companies Act. Its infrastructure and research activities are funded through fees paid by member organizations, an infrastructure grant from the Ministère de la Recherche, de la Science et de la Technologie, and grants and research mandates obtained by its research teams.

\section{Les organisations-partenaires / The Partner Organizations}

-École des Hautes Études Commerciales

-École Polytechnique

-Université Concordia

-Université de Montréal

-Université du Québec à Montréal

-Université Laval

-Université McGill

-Ministère des Finances du Québec

-MRST

-Alcan inc.

-AXA Canada

-Banque du Canada

-Banque Laurentienne du Canada

-Banque Nationale du Canada

-Banque Royale du Canada

-Bell Québec

-Bombardier

-Bourse de Montréal

-Développement des ressources humaines Canada (DRHC)

-Fédération des caisses Desjardins du Québec

-Hydro-Québec

-Industrie Canada

-Pratt \& Whitney Canada Inc.

-Raymond Chabot Grant Thornton

-Ville de Montréal

(C) 2001 Maher Kooli et Jean-Marc Suret. Tous droits réservés. All rights reserved.

Reproduction partielle permise avec citation du document source, incluant la notice $\odot$.

Short sections may be quoted without explicit permission, if full credit, including $\odot$ notice, is given to the source.

Ce document est publié dans l'intention de rendre accessibles les résultats préliminaires

de la recherche effectuée au CIRANO, afin de susciter des échanges et des suggestions.

Les idées et les opinions émises sont sous l'unique responsabilité des auteurs, et ne représentent pas nécessairement les positions du CIRANO ou de ses partenaires.

This paper presents preliminary research carried out at CIRANO and aims at encouraging discussion and comment. The observations and viewpoints expressed are the sole responsibility of the authors. They do not necessarily represent positions of CIRANO or its partners. 


\title{
The Underpricing of Initial Public Offerings: Further Canadian Evidence*
}

\author{
Maher Kooli ${ }^{\dagger}$, Jean-Marc Suret \\ Résumé / Abstract
}

La présente étude propose une analyse en profondeur du comportement des émissions initiales canadiennes de 1991 à 1998, en incluant les titres émis dans le cadre des programmes de Capital Pool. Les résultats montrent que la sous évaluation initiale persiste au Canada, en moyenne. Toutefois, le degrés de sousévaluation est fortement lié au type d'émission : les émissions d'unités et celles qui se font dans le cadre des programmes de Capital Pool sont davantage sous évaluées que les émissions d'actions ordinaires hors Capital pool. Les émissions de taille moyenne et de grande taille semblent correctement évalués au Canada, contrairement à ce que l'on observe sur la plupart des marchés et notamment aux États-Unis. La sous-évaluation initiale concerne donc essentiellement les émissions de 20 millions de $\$$ et moins, qui représentent toutefois 76,3 p. cent des émissions analysées. La sous-évaluation initiale reste donc un problème majeur pour les petites et moyennes entreprises canadiennes. Parmi les autres explications possibles à la sous-évaluation initiale, seule la période d'émission semble jouer un rôle significatif, en plus de la taille et de l'appartenance ou non au programme des Capital Pool.

Evidence of underpricing of initial public offerings (IPOs) has spawned a considerable theoretical literature attempting to explain the apparent contradiction to market efficiency. This article reassesses that evidence by examining not just common shares Canadian IPOs, but also unit and Junior stock IPOs from the period 1991-1998. Our study shows that Canadian IPOs as major IPOs in the world are underpriced. However, the degree of underpricing depends on the type of the issue. Unit IPOs and Junior Capital Pool (JCP) IPOs are more underpriced than common shares IPOs. Our results also suggest that the IPO market in Canada is "good» only for large offerings. We have entertained a number of possible explanations for the high initial return of Canadian issuing firms. We find that the underpricing is significantly related to the size and the period of the issue and to whether the IPO is a JCP or not. On the other hand, the prestige of the underwriter is positively related to the underpricing but this relationship is not significant.

Mots Clés : Émissions initiales, sous évaluation, Canada

Keywords: Initial public offerings, underpricing, hot market

\footnotetext{
* Corresponding Author: Jean-Marc Suret, CIRANO, 2020 University Street, $25^{\text {th }}$ floor, Montréal, Qc, Canada H3A 2A5 Tel.: (514) 985-4000 Fax: (514) 985-4039 email: jean-marc.suret@fsa.ulaval.ca

CIRANO

$¥$ Université Laval and CIRANO
} 


\section{Introduction}

The existence of the underpricing phenomenon in initial public offerings (IPOs) is well documented by the finance literature, and seems to be a common characteristics in most of international markets. Recently, with high-tech and Internet stock offerings making huge gains on their market debuts, investors, analysts and researchers have again focused their attention on the IPO market. Why are some IPOs more underpriced than others?

Several reasons have been advanced for the underpricing phenomenon with different theories focusing on various aspects of the going public process. Furthermore, these explanations are not mutually exclusive. This research makes three contributions to the IPO literature. First, despite the persistence of the phenomenon and its internationality, researchers are still looking for the reasons that fit with modern financial theories. Ritter (1998) argues that the underpricing phenomenon has persisted for decades with no signs of its imminent demise. Second of all, only few studies have analyzed the Climate of IPOs in Canada and they were for the 1980s period. It would be interesting to reexamine the underpricing phenomenon during the 1990s. The new issues market in Canada has changed considerably in the last decade. There are many more IPOs being issued now. The type and the quality of companies going public have also changed over time. Brean (1997) points out that "Overpriced IPOs represent excessive rewards to venture capital, an allocative inefficiency in financial markets. On these matters, the evidence in Canada is slim but suggestive". Jog (1997) has analyzed the underpricing phenomenon of the Canadian Stock Market between 1984 and 1994 and pointed out that Canadian capital markets are doing a good job in allocating risk capital to entrepreneurs and those Canadian entrepreneurs and policy makers need not to be too concerned about underpricing in Canada. Nevertheless, the reasons for the declining average underpricing observed by the author are unclear. He also adopted a limited sample of IPOs listed only on the Toronto Stock Exchange. To assess the Canadian climate for IPOs, information on the four Canadian stock markets is needed. Differences in both the regulatory aspects of the various exchanges and the firms going public may affect the IPO process. Third, the Canadian environment is motivating because a large number of the quoted companies are relatively small. Furthermore, the institutional characteristics of the Canadian market allow for an independent test of the most well-known issues in the US literature. Therefore, the aim of our research is to widen the sample size, to update the previous results and point out the role of the underpricing determinants. In a new approach, we consider not only the effects of several factors, namely the gross proceed of the issue, the role of underwriter, the industry and the market climate, but we also examine the short term behaviour of three different types of unseasoned issues: common stock issues, units issues and junior stock issues.

Using a wide sample of 971 Canadian IPOs from the period 1991-1998, we find that the average initial return for common shares IPOs (excluding junior stocks) was 20,57\% (22,57\% with a market adjusted measure). However, the degree of underpricing depends on the type of the issue. Unit IPOs and Junior Capital Pool (JCP) IPOs are more underpriced than common shares IPOs. Our univariate analysis suggests that the IPO market in Canada is «good» only for large offerings. Also, we find that underpricing decreased with the size of the issue and the prestige of the underwriter and that mining, oil and gas, real estate and technology IPOs are more 
underpriced than those from other sectors. Interestingly, we find that the Albertan and British Columbia IPOs are more underpriced than Ontarian IPOs. This result may be explained by the experience of large firms who are listed on the Toronto Stock Exchange. We have entertained a number of possible explanations for the high initial return of Canadian issuing firms. We find that the underpricing is significantly related to the size and the period of the issue and to whether the IPO is a JCP or not. On the other hand, the prestige of the underwriter is positively related to the underpricing but this relationship is not significant.

The remainder of this paper is organized as follows. Section 1 reviews some of the international literature on IPO's underpricing and underlines some of the reasons for this phenomenon. We also discuss the methodological dimension of measuring the degree of underpricing. Section 2 contains a discussion of the data and the methodology used in the empirical investigation. Evidence on underpricing is presented in the section 3. We also present the cross-sectional patterns and the results of the multiple regression tests. Section 4 summarizes the findings and provides concluding remarks.

\section{The evidence of underpricing}

Many past studies have indicated that the IPO of common stock have been often notably undervalued in the primary market, with some movement towards a security's intrinsic value observed in secondary trading. This short-run phenomenon has been experienced in every country with a stock market, although the degree of underpricing varies from country to country (see table 1). The next section resumes some of the empirical studies that document large abnormal returns on the first day of trading and give us a theoretical backdrop for the empirical results.

\subsection{Prior research}

In the U.S. early studies that document huge underpricing for IPO include Ibbotson and Jaffe (1975), Ritter (1984 and 1991) and Loughran, Ritter and Rydqvist (1994). Ibbotson and Jaffe (1975) examined the existence of «hot issue » markets and found that a time series of IPO returns exhibited serial dependence and that « hot issue » markets persist over time. Ritter (1984) suggested that the phenomena of «hot issue » markets is restricted to natural resource securities and that over the 15 months beginning January 1980, U.S. IPO securities experienced a gain of $48,8 \%$ on the first day of trading. The study of Loughran, Ritter and Rydqvist (1994) confirmed this IPO underpricing phenomenon in 25 countries, with higher IPO underpricing in developing than in developed markets. For example, the level of underpricing in the US was 15,3\% (for 10,626 IPOs during 1960-92), in France was 4,2\% (for 187 IPOs during 1983-92) and in Malaysia was 80,3\% (for 132 IPOs during 1980-91). Lowry and Schwert (2000) find that the number of IPOs and the average initial returns are highly autocorrelated and that both price update and the initial return are predictable based on publicly available information. Huang and Levich (1998) also find that initial returns for non OECD countries average 65,9\% versus 11,1\% initial returns in OECD countries. They suggest that these differences are highly significant and 
provide strong evidence favouring the asymmetric information theory. Su and Fleisher (1999) analyse Chinese IPOs during the period of 1985-1987 and find that the level of underpricing for A-shares is $948,6 \%$. Arosio, Giudici et Paleari (2000a) analyse a survey of Internet stock IPOs, listed on the Euro's secondary Stock Exchanges ${ }^{1}$ and find an initial average return equal to $76,43 \%$. They document that this huge underpricing is strongly related to the information gathered during book-building activity in the pre-selling period, which drives the revision of the prospectus price range and signals the IPO quality to uninformed investors. Chowdhry and Sherman (1996) document that the average first-day return varies systematically with the mechanism used to price and distribute IPOs. Ritter (2001) points out that fixed price offerings are more underpriced than offerings built by the book. Ljungqvist, Jenkinson and Wilhelm (2000) analyse 2105 IPOs in 61 non-US markets during the period 1992-1999 and document that the direct costs of book-building are twice as large as direct costs for fixed-price offers, but the bookbuilding leads to substantially less underpricing. On the other hand, Derrien and Womack (2000) analyse the French IPOs market during the period 1992-1998 and find that auctions IPOs are less underpriced $(9,7 \%)$ than book-building IPOs (16,9\%). For Taiwan, Liaw, Liu and Wei (2000) find that the degree of underpricing for price-fixed IPOs is $34,6 \%$ and $7,8 \%$ for auctions IPOs. Kutsuna and Smith (2000) also point out that in Japan, auctions IPOs are less underpriced $(11,50 \%)$ than book-building IPOs $(70,81 \%)$.

Canadian studies of IPOs that report underpricing include Jog and Riding (1987), Suret, Cormier and Lemay (1990), Jog and Srivastava (1994) and Jog (1997). Jog and Riding (1987) reported that short-term returns following the IPO averaged 11,5\% between 1971 and 1983. Suret, Cormier et Lemay (1990) reported average initial returns of $12 \%$ for 86 Toronto Stock Exchange IPOs, over the period 1979 to 1985, and no underpricing for 63 IPOs issued under the Quebec Stock Saving Plan (QSSP). Jog and Srivastava (1994) extended the empirical analysis of Jog et Riding (1987) and reported average initial returns of 5,67\% between 1984 and 1992. Jog (1997) again extended the analysis of Jog and Srivastava (1994), considering all the Canadian IPOs made from 1993 to 1994 and reported average initial returns of 7,89\%. Jog (1997) point out that the degree of underpricing in Canada was much lower in the 1980s and the early 1990s than had been reported for previous periods. Finally, Jog and Srivastava (1994) and Jog (1997) conclude that Canadian capital markets are doing a good job in allocating risk capital to entrepreneurs, and there is no reason to be concerned about the pricing mechanism for Canadian IPOs. However, this evidence is restricted to firms which qualified for listing on the Toronto Stock Exchange (TSE). Although the TSE is Canada's largest exchange, it is dangerous to assume that the results drawn from it necessarily apply to the other public equity markets. Differences in the listing requirements and other regulatory aspects of the various exchanges may affect the IPO process. For example, over the period 1983 to 1988, Falk and Thornton (1992) reported average adjusted initial returns of $19 \%$ for TSE IPOs, 25\% for Montreal Exchange (ME) IPOs and 307\% for

\footnotetext{
${ }^{1}$ Arosio, Guidici et Paleari (2000a) consider in their study the pan-European second markets (EASDAQ and EURONM). EASDAQ is a Belgian stock market founded in 1996 by US and European financial intermediates. Euro-NM is a network of regulated national markets made up by the German Neur Markt, the Dutch Euro-NM Amsterdam, the Belgian Euro-NM Belgium and the Italian Nuovo Mercato.
} 
Alberta Stock Exchange (ASE) IPOs. Their sample of ASE securities included both regularly listed ASE and JCP securities.

Several explanations are possible for these cross-country differences. Institutional differences probably play an important role, as underwriters follow different price setting and allocation strategies across country (auctions IPO, direct public offerings, book-building offerings, etc...).

\subsection{Underpricing and ex ante uncertainty}

In this section, we will take a conceptual look at the sources of underpricing, so as to define the theoretical backdrop for the empirical results. Several hypothesis ${ }^{2}$ have been proposed that focus on one or more players in the IPO process (the current owner of the firm, the underwriter and the potential new shareholders). Generally, these theoretical explanations are not mutually exclusive. Ritter (1998) points out that all the explanations for the underpricing phenomenon can be criticized on the grounds of either the extreme assumptions that are made or the unnecessarily convoluted stories involved. On the other hand, most of the explanations have some element of truth to them and agree on the fact that the degree of underpricing should be increasing in the ex ante uncertainty of the issue (Beatty and Ritter, 1985), where ex ante uncertainty is defined as the uncertainty about the offering's value once it starts trading. This suggests that there should be a relationship between the degree of underpricing and the gross proceed of the firm or of the issue, the choice of the underwriter and the market climate.

\subsubsection{Size and Underpricing}

A substantial body of literature examines the effect of size on the initial return of IPOs. On balance, the empirical evidence suggests that smaller IPO is more risky than a larger IPO, ceteris paribus. Therefore, smaller IPO is more underpriced than larger IPO. This result was confirmed by Ritter (1987), Chalk and Peavy (1990), Jog and Riding (1987), Suret, Cormier and Lemay (1990) and Clarkson and Merkley (1994). Carter and Manaster (1990) document that, in maximizing the value of their information acquisition, the informed investors (the institutions) will take into account not only the degree of uncertainty in a given issue but also its size. The bigger the IPO, the greater the potential gains from acquiring information about the issue.

\subsubsection{Role of underwriter and underpricing}

Underwriters provide a wider range of services, they act as intermediaries between the firm and investors in marketing and distributing the shares, in timing the IPO and in fixing the price and the volume of the offer.

\footnotetext{
2 Among these hypothesis, we note the winner's curse hypothesis, the market feedback hypothesis, the bandwagon hypothesis, the investment banker's monopsony power hypothesis (Chalk and Peavy 1987 and Ritter 1984, the lawsuit hypothesis, the signalling hypothesis (Allen and Faulhaber, 1988 and Welch, 1989), and the ownership dispersion hypothesis. See Ritter (1998) for a review of these explanations.
} 
Rock (1986) developped a model, in which there are two classes of investors : informed investors and uninformed investors. The informed investors are able to determine the investment quality of a particular IPO and will attempt to purchase a large amount of the underpriced IPOs and a lesser amount of the overpriced IPOs. The uninformed investors are unable to differentiate between the types of IPOs and will wind up purchasing a higher percentage of the overpriced IPOs and a lower percentage of the underpriced IPOs. Therefore, uninformed investors face a winner's curse: the probability of being allocated shares of overpriced new issues is greater than underpriced issues. To keep uninformed investors participating in the IPO market, underwriter underprices to ensure them a non-negative rate of return and to cover their losses on the overpriced IPOs. Beatty and Ritter (1986) suggest that underwriters will enforce the IPO underpricing to maintain their reputation. Though, a systematically too high or too low underpricing would subsequently be followed by a loss in their market share. The underwriter would thus be seen to underprice a strong issue as much as it can get away with without losing reputation. Titman and Trueman (1986), Carter and Manaster (1990), Maksimovic and Unal (1993) and Carter, Dark and Singh (1998) find that high reputation underwriters underprice less than non prestigious underwriters. This is because high reputation underwriter issue firms with lower ex ante uncertainty. On the other hand, Ljunqgvist (1999) analyse US IPOs during the 1990s and find that more prestigious underwriters are associated with higher underpricing. He postulates that this result may be explained by a possible conflict of interest between venture backers and entrepreneurs. Beatty et Welch (1996) suggest that there should be a positive relationship between the underpricing and the underwriter reputation. In Canada, Clarkson and Merkley (1994) confirm the certification role of the underwriter. Suret, Cormier and Lemay (1990) analyse 63 IPOs issued under the Quebec Stock Savings Plan (QSSP) and find a negative but not significant relationship between the level of underpricing and the underwriter reputation. They suggest that the high participation of low reputation underwriters may explain their result.

\subsubsection{Market climate and underpricing}

Many researchers have found that issuers or underwriters are able to successfully time their offerings when the market is optimistic about IPOs in general and when the demand for IPOs is high, in order to achieve a smooth distribution of shares and raise a large amount of capital. Derrien and Womack (2000) suggest that the current market climate plays an important role in determining an IPO's underpricing. Indeed, in euphoric or hot markets, investors may be overly optimistic about a firm's prospects, causing the aftermarket equilibrium price to be greater than in normal conditions. Furthermore, market climate not only affects the number of successful offerings but also the amount and the variability of IPO's underpricing. For example, when the market is "hot", the level of underpricing may double or even triplicate. On the other hand, if the market is "cold", the level of underpricing would be much lower. Loughran and Ritter (2001) point out that underpricing is a form of indirect compensation to underwriters to gain favourable allocations on hot issues. How, Izan and Monroe (1995) analyse the Australian IPO market and confirm that the level of underpricing is high during hot periods and low during cold periods. Helwege and Liang (1996) find that 575 firms went public in the hot issue year of 1993, whereas 
in the cold issue year of 1988 the number of firms was only the quarter of 1983. Furthermore, the level of underpricing averaged 14,6\% in 1983 and 6,6\% in 1988. Ljungqvist (1997) reports that a positive macroeconomic climate raises the average amount of underpricing. Hoffmann-Burchardi (2001) find that the IPO market is subject to dramatic swing. He suggests that the IPO price of one firm serves as feed-back mechanism to other IPOs since it can reveal information about a certain common value factor about the prospects for a specific industry and therefore change the value of other firms. The revelation of this common value factor may explain the clustering phenomena like hot issue markets. Lowry and Schwert (2000) find that initial returns are significantly negatively correlated with past IPO volume and significantly positively correlated with future IPO volume. They point out that if high average initial returns indicate that the sentiment is especially high or market conditions are better than expected, then more companies are likely to subsequently go public. As more firms go public, the uncertainty surrounding the true value of these firms decreases, thus causing average initial returns to decrease.

These relationships between underpricing and the size of the issue, the underwriter reputation and the market climate allow us to suggest the following hypothesis, which are tested at the end of the section 3 .

Hypothesis $\mathbf{H}_{1}$ : Ex-ante uncertainty hypothesis: a negative relationship exists between the level of underpricing and the ex-ante uncertainty measured by the size of the issue.

Hypothesis $\mathbf{H}_{2}$ : Underwriter reputation hypothesis: a negative relationship exists between the level of underpricing and the reputation of the underwriter.

Hypothesis $\mathbf{H}_{3}$ : Market climate hypothesis: IPOs issued during an upswing in the stock market experienced a higher underpricing than IPOs issued during a falling market.

We test these hypothesis in section 3. In the next section, we discuss the problems inherent to the measure of IPO's underpricing.

\subsubsection{Methodological dimension}

In reviewing the international evidence, we conclude that two factors could be an important determinants of IPO underpricing, namely constraints on price setting and allocations of new shares, and differences in litigation environment. However, as documented by Lee, Taylor and Walter (1996), institutional characteristics peculiar to a domestic environment and IPO's mechanism for pricing cannot fully explain an anomaly which has proven pervasive throughout the world. Therefore, the purpose of this section is to examine whether the international results were sensitive to the methodology considered to measure the degree of underpricing.

The pricing of IPOs is difficult partly because there is no observable market price prior to the offering and partly because many of the firms going public have little or no operational history. To measure the level of underpricing, previous studies use the conventional method where the initial return available to the subscribers is given by 


$$
\text { Initial return }_{\mathrm{i}}=\frac{(\mathrm{Pm}-\mathrm{Pe})}{\mathrm{Pe}}
$$

where $\mathrm{P}_{\mathrm{m}}=$ First day price and $\mathrm{P}_{\mathrm{e}}=$ Offer price.

Nonetheless, the return measured by equation (1) would be valid in a market, where there is no time gap between the application closing date and the first day of trading ${ }^{3}$ and no rationing takes place. If during this period, a major change occur in market conditions, we should adjust for market return in the raw return estimated by equation (1).

$$
\text { Initial return }{ }_{i}=\frac{\left(\mathrm{P}_{\mathrm{m}}-\mathrm{P}_{\mathrm{e}}\right)}{\mathrm{P}_{\mathrm{e}}}-\frac{\left(\mathrm{M}_{1}-\mathrm{M}_{0}\right)}{\mathrm{M}_{0}}
$$

where $\mathrm{P}_{\mathrm{m}}=$ First day price; $\mathrm{P}_{\mathrm{e}}=$ Offer price; $\mathrm{M}_{1}=$ Market index on the first day of trading;

$\mathrm{M}_{0}=$ Market index on the application closing day. This measure supposes that the market beta of the stock is 1 .

The third approach used by researchers to measure the underpricing's level is to adjust for the systematic risk of the firm. The initial return available to the subscribers would be given by

$$
\text { Initial return }_{i}=\frac{\left(\mathrm{P}_{\mathrm{m}}-\mathrm{P}_{\mathrm{e}}\right)}{\mathrm{P}_{\mathrm{e}}}-\beta_{\mathrm{i}} \frac{\left(\mathrm{M}_{1}-\mathrm{M}_{0}\right)}{\mathrm{M}_{0}}
$$

where $\mathrm{P}_{\mathrm{m}}=$ First day price; $\mathrm{P}_{\mathrm{e}}=$ Offer price; $\mathrm{M}_{1}=$ Market index on the first day of trading; $M_{0}=$ Market index on the application closing day and $\beta_{i}=$ Systematic risk of the firm $i$.

This measure is however subject at least to one potential bias. Indeed, as stock is infrequently traded in the aftermarket periods, the OLS beta estimates are asymptotically biased downward and tend to overestimate the excess returns (Scholes et Williams, 1977 et Dimson, 1978). To overcome this problem, we suggest the Scholes-Williams technique, which requires three beta estimates "from the previous $\left(\beta^{-1}\right)$, current $\left(\beta^{0}\right)$ and subsequent $\left(\beta^{+1}\right)$ periods" of a market model and the autocorrelation coefficient $\left(\rho_{1}\right)$ of the market index. The beta adjusted for infrequent trading is

$$
\begin{gathered}
\beta=\frac{\left(\beta^{-1}+\beta^{0}+\beta^{+1}\right)}{\left(1+2 \rho_{1}\right)} \\
\text { where } \beta^{-1}=\frac{\operatorname{covariance}(R m, t ; R, t-1)}{\operatorname{variance} R_{m}}
\end{gathered}
$$

where $\mathrm{R}_{\mathrm{m}}=$ market return on the $t$ th trading day $; \mathrm{R}_{\mathrm{i}}=$ return on new issue $\mathrm{i} .{ }^{4}$.

\footnotetext{
${ }^{3}$ In the US and Canada, the time gap is quite short (about at most one week). In Malaysia, the time gap is much longer, an average of five weeks, and in some cases it may even reach two months (Pauydal, Saadouni et Briston, 1998). Mok et Hui analyse Chinese IPOs and find that one day increase in the time gap between offering and listing rises the level of underpricing by a factor of $0,69 \%$.

${ }^{4}$ The difficulty of measuring the beta for IPOs may explain the reluctance of using the equation (13) to measure the degree of underpricing.
} 
Ritter (1991) uses the benchmark-adjusted return as an alternative measure of IPO underpricing, defines as

$$
\mathrm{AR}_{\mathrm{it}}=\mathrm{R}_{\mathrm{it}}-\mathrm{R}_{\mathrm{mt}}
$$

where $R_{i t}$ and $R_{m t}$ are respectively, the return for firm $i$ and the return on the benchmark $m$ on the $t$ th trading day. The average benchmark-adjusted return on a portfolio of $n$ stocks for event month $t$ is the equally-weighted arithmetic average of the benchmark-adjusted returns:

$$
\mathrm{AR}_{\mathrm{t}}=1 / \mathrm{n}_{\mathrm{t}}\left(\sum_{i=1}^{n t} A R_{i t}\right)
$$

Empirical results of various studies presented in table 2 indicate that the adjusted market measure is the most used to calculate the underpricing's level. Affleck-Graves, Hedge and Miller (1996) measure the level of underpricing for US IPOs during the period 1975-1985, using the non adjusted and the market adjusted measures and find that there is no significant difference between the mean of the underpricing calculated by the two approaches. This is generally the case when the time gap between the offering and the listing is short. Indeed, Mok and Hui (1998) analyse Chinese IPOs and find that taking account of the overall market effect would yield substantial difference in the results if the time gap is large. For example, the non adjusted IPO underpricing for A-shares is 362,3\%, much higher than the adjusted IPO underpricing for the same shares (which is $289,2 \%$ ). The time gap for A-shares is 307 days. For B-shares new issues, where the time gap is only 20 days, the non adjusted IPO underpricing is $24,9 \%$ and the adjusted IPO underpricing is $26,2 \%$.

In this paper, to examine whether our results are sensitive to the dimension methodology, we use the non adjusted and the adjusted measures for the underpricing's level. This will also help us in comparing our results with previous studies.

\section{Data and methodology}

Canadian stock markets includes four markets and the OTC (the-over-the-counter) market. Among four markets, the Toronto Stock Exchange (TSE) is Canada's premier market for senior equities, accounting for approximately $95 \%$ of all equity trading in Canada.

Procedures for issuing unseasoned equity in Canadian markets are similar to those for the US markets. In most cases, an issuer and underwriter determine the offering price to investors before the offering date, and the new shares are distributed at that price on the offering day. If the underwriter receives orders that exceed the number of shares to be distributed, rationing will occur. That is, the underwriter allocates the shares among investors, based on his discretion. The first aftermarket price is then established at the point where the supply and demand for the new issues are balanced.

One of the particular characteristics of Canadian market IPOs is the existence of the Junior Capital Pool program which was initiated in November 1986. This program is introduced in Alberta and is similar to the blind pool programs that were implemented in the 1980s in the U.S. 
to assist start-up firms raising equity. Unfortunately, the experience of U.S. investors with blind pools has been poor (see Stern and Bornstein, 1986). In Canada, Robinson (1997) shows that the JCP program has been successful in helping entrepreneurs use the public equity markets to raise the initial capital for their business. The program reduces the regulatory cost, yet it is still monitored and regulated at a high level.

To set up a JCP firm, a group of inside investors raises seed capital by issuing themselves shares in exchange for cash. The amount of seed capital required is $\$ 100,000$. The firm raises additional equity capital through a JCP IPO to outside shareholders with a minimum share value of at least $\$ 0,10$. From the start, the JCP program was transitory. JCP firms had a limit of 18 months in which to complete their major transaction or they were delisted by the Alberta Stock Exchange (ASE). This major transaction - an asset acquisition- will change the company from a JCP firm to a regularly listed ASE firm. It is possible that this 18-month period may force some outside shareholders to make suboptimal investment decisions near the end of the period if they are concerned being delisted. The ASE has combat this potential problem by allowing JCP firms to became reinstated if they complete a major transaction after the 18 -month period. In its early years, the JCP program has started with the listing of oil and gas firms. Over time, it has diversified its listings to include the manufacturing, services and high-technology sectors. From interviews with JCP principals and underwriters, Hopkins and Robinson (1994) concluded that the JCP program is a viable program for financing small Canadian firms.

Our original sample numbered 1373 IPOs $^{5}$ listed in the Toronto Stock Exchange, Montreal Stock Exchange, Vancouver Stock Exchange and Alberta Stock Exchange. The primary source of data is the "Record of New Issues: Annual Report by the Financial Post Datagroup" which reports offering dated, offering prices, issue size and the name of the underwriter. Out of these original sample, 402 IPOs had to be dropped for three reasons: First, Datastream used to obtain the prices at the end of the first day of trading and the last day of the period does not cover the over the counter $(\mathrm{CDN})$ listed companies. Second, return data, proceed of offering or price issue were not available. Third, 22 IPOs were listed on the US market. This resulted in a final sample of 971 IPOs between January 1991 and December 1998. Our sample is composed as follows:

\section{Common shares IPOs 878 (of which 433 JCP IPOs)}

Unit IPOs 93

We use a large sample of Canadian IPOs including JCP and unit offerings. We hope that this approach will shed some light on the underpricing phenomenon. Unit offerings are included as an important source of financing for many small firms ${ }^{6}$. Although, they have received little attention in the finance literature. Lee, Lee and Taylor (2000, p. 3) point out that « Yet, although practioner explanations for unit IPOs may seem unsatisfactory, there is relatively little analytical or empirical evidence on their use». How and Howe (2001) also document that evidence on units

\footnotetext{
${ }^{5}$ Closed-end funds and real estate investment trusts companies are excluded from our sample.

${ }^{6}$ How et Howe (2001) find that among a sample of 394 Australian IPOs, occurred during the period 1979-1990, 134 IPOs are unit offerings (which represent $34 \%$ of the sample). Schultz (1993) also find that among a sample of 797 US IPOs, occurred during the period 1986-1988, 167 IPOs are unit offerings (which represent $21 \%$ of the sample).
} 
IPOs is needed. As far as we know, prior Canadian empirical research is limited to common shares IPOs.

Table 3 presents the distribution of the sample by year, both in terms of the number of offers and the gross proceeds. Inspection of table 3 shows that the 655 of the 971 sample offers $(67,45 \%)$ occurred over 1993, 1994, 1996 and 1997. 61,32\% (\$10243,7 millions of the $\$ 16703,9$ millions total) of the aggregate gross proceeds in the sample was raised in these four years alone and the rest $(38,67 \%$ or $\$ 6460,2$ millions of the $\$ 16703,9$ millions total) was raised by the 316 IPOs occurred over 1991, 1992, 1995 and 1998. This result is consistent with the notion of hot issues market (Ritter, 1991). Following this, we consider the years 1993, 1994, 1996 and 1997 as hot period and 1991, 1992, 1995, 1998 as cold period. Table 3 also suggests that the size of unit IPOs is smaller than common shares IPOs. This was also the case in the US (Schultz, 1993) and Australia (Lee et col., 2000). Schultz (1993) points out that firms making unit offerings are typically smaller, younger and riskier than firms that go public via a share IPO.

$$
* * * \text { Table } 3 * * *
$$

Table 4 presents the distribution of the sample by province, both in terms of the number of offers and the gross proceeds. Inspection of table 3 shows that the sample is diversified across four provinces: The largest amount of gross proceeds is from Ontario ( $\$ 8864,18$ millions for 190 IPOs of 971 total IPOs, 5,3\%), followed by Quebec (\$2281,5 millions for 52 IPOs of 971 total IPOs, 10,78\%), Alberta (\$2028,61 millions for 547 IPOs of 971 total IPOs, 56,33\%) and British Columbia (\$1218,24 millions for 144 IPOs of 971 total IPOs, 14,83\%). It appears from table 4 that the Ontario IPO-market is the largest one.

$$
* * * \text { Table } 4 * * *
$$

Table 5 presents the distribution of the sample by industry ${ }^{7}$, both in terms of the number of offers and the gross proceeds. Inspection of table 5 shows that the sample also covers different industries. Production IPOs represent 84 IPOs of 971 total IPOs and about 23,5\% of the aggregate gross proceeds in the sample were raised by this industry. The gross proceeds for Technology IPOs were $\$ 2899,45$ millions of the $\$ 16703,9$ millions total. Oil and gas and mining, both, represent 202 IPOs of 971 total IPOs (20,8\% of the sample). About 20,4\% (\$3406,9 millions of the $\$ 14657,9$ millions total) of the aggregate gross proceeds in the sample were raised by these industries.

$$
\text { *** Table } 5 * * *
$$

We use two methods to measure the level of underpricing. The first measure is the conventional one and is given by

$$
\mathrm{UND}(1)_{\mathrm{i}}=\frac{(\mathrm{Pm}-\mathrm{Pe})}{\mathrm{Pe}}
$$

\footnotetext{
${ }^{7}$ Our segmentation by industry is based on the classification of the System for Electronic Document Analysis and Retrieval (SEDAR) available at the following address: www.sedar.com.
} 
where $\mathrm{P}_{\mathrm{m}}=$ First day price and $\mathrm{P}_{\mathrm{e}}=$ Offer price.

The second measure is given by

$$
\operatorname{UND}(2)_{i}=\frac{\left(P_{m}-P_{e}\right)}{P_{e}}-\frac{\left(M_{1}-M_{0}\right)}{M_{0}}
$$

where $\mathrm{P}_{\mathrm{m}}=$ First day price; $\mathrm{P}_{\mathrm{e}}=$ Offer price; $\mathrm{M}_{1}=$ Market index on the first day of trading;

$\mathbf{M}_{0}=$ Market index on the application closing day. This measure supposes that the market beta of the stock is 1 . We use the TSE 300 index as a market index.

\section{Results}

\subsection{The underpricing phenomenon in Canada}

$$
* * * \text { Table } 6 * * *
$$

Table 6 contains a descriptive statistics of the degree of underpricing for a sample of 971 Canadian IPOs from the period 1991-1998. The average initial return (UND) for the common shares IPOs (excluding JCP IPOs) was $20,57 \%$ with a t-value of 7,65 . the adjusted measure was $22,11 \%$ with a t-value of 7,84. In line with previous studies, we conclude that Canadian IPOs are underpriced as most IPOs in the world ${ }^{8}$. Our results are however inconsistent with those of Jog (1997), who analyse a sample of 254 IPOs from the period 1984-1992 and find a degree of underpricing of $7,89 \%$. This difference may be explained by the fact that Jog consider only Toronto Stock Exchange Listed IPOs. Differences in both the regulatory aspects of the various Canadian exchanges and the firms going public may affect the IPO process and the degree of underpricing as well. For example, firm size may be smaller for some exchanges. So too may be the involvement of institutional investors and the market climate. The study of these effects is presented in the next section.

Table 6 also reveals that JCP IPOs are more underpriced than non JCP IPOs. The average initial return was huge $(135,41 \%$ with $\mathrm{UND}(1)$ and $140,88 \%$ with $\mathrm{UND}(2))$. The t-value on the difference in average initial return between JCP and non JCP IPOs is significant at $1 \%$ level $^{9}$. The high level of underpricing for JCP IPOs may be explained by the characteristics of the securities, e.g., risk and return and their low issue prices, which are usually set between 10 and 20 cents. Robinson (1997) analyse JCP IPOs and find a non adjusted average initial return of $248 \%$ for the period between 1987 and 1988 and a non adjusted average initial return of $68 \%$ for the period between 1988 and 1992. He concludes that the dramatic reduction in the underpricing degree may be explained by the fact that Canadian investors became accustomed to the characteristics of the JCP program. However, our results suggest that, the investor's attitude had

\footnotetext{
${ }^{8}$ Guidici et Paleari (1999) find an average underpricing of 23,87\% for Italian IPOs, Derrien et Womack (2000) find an average underpricing of $13,23 \%$ for French IPOs, Paudyal, Saadouni et Briston (1998) find an average underpricing of $61,8 \%$ for Malaysian IPOs and Ritter (1998) find an average of 15,8\% for US IPOs.

${ }^{9}$ We also carried out two non parametric tests ( the Kruskal-Wallis and the Mann-Whitney). The results suggest the average initial return offered by the JCP IPOs is significantly higher than that available from non JCP IPOs.
} 
not changed and the reduction in underpricing observed by Robinson is principally related to the market climate during the period of analysis. It is important to note that 1991 and 1992 were cold periods in the Canadian markets.

Continuing, Table 6 also reveals that units IPOs are more underpriced than common shares (excluding JCP) IPOs. The average initial return was 40,59\% with UND(1) and 41,50\% with $\mathrm{UND}(2)$. The $\mathrm{t}$-value on the difference in average initial return between units and non units IPOs is significant at a $1 \%$ level $^{10}$. Our results are consistent with those of Schultz (1993) and How and Howe (2001). For a sample of 797 United States IPOs from 1986 through 1988, Schultz (1993) documents that 167 firms making unit offerings are typically smaller, younger and riskier than those making common shares offerings. For a sample of 394 Australian IPOs from 1979 through 1990, How and Howe (2001) find a degree of underpricing of 68,57\% for units IPOs and of $40,64 \%$ for common shares IPOs. The high percentage of underpricing for units IPOs and JCP IPOs may be, in part, explained by the small size of the offerings. We test this relation in the next section.

Table 6 also reveals that the distribution of the degree of underpricing is not stationary. In 1991, common shares IPOs (excluding JCP) were slightly overpriced (UND $(1)=-4,85 \%$ and UND=$5,26 \%$ ). In 1992, the degree of underpricing increased but this was due the high underpricing of two following firm's IPOs: Primo Gold Limited (UND(1)=300\%) and Quest Technologies Inc. $(\mathrm{UND}(1)=350 \%)$. If we eliminate these two IPOs ${ }^{11}$, the degree of underpricing for 1992 would be 6,22\% (with UND(1)). In 1993 and 1994, the average initial return increased while in 1995, it decreased. In 1996, the underpricing's level increased by 107,31\% according to 1995's average initial return. In 1997, the degree of underpricing reach a maximum of 39,30\% with UND(1) $(45,13 \%$ with UND(2)). It is important to note that 1997 was a hot issue period with a maximum of $\$ 3328,5$ millions $^{12}$ collected through IPOs. In 1998, the number of IPOs and the degree of underpricing were decreased ${ }^{13}$. Our results suggest that 1993, 1994, 1996 and 1997 may be considered as hot periods, while 1991, 1992, 1995 and 1998 may be considered as cold periods. Ibbotson and Jaffe (1975) also show that hot period is usually characterized by high volume of issues and a high average initial return and then followed by a decrease in the level of underpricing. The same pattern is observed for units IPOs and JCP IPOs. Stoughton, Wong and

\footnotetext{
${ }^{10}$ We also carried out two non parametric tests ( the Kruskal-Wallis and the Mann-Whitney). The results suggest the average initial return offered by the units IPOs is significantly higher than that available from non unit IPOs.

${ }^{11}$ We could use a value weighted average initial for the degree of underpricing. However, as mentioned in several studies, the underpricing phenomenon is particular present in small offerings. The value weighting schema decrease considerably the degree of underpricing especially for IPOs with gross proceeds under one million dollars, which represent $68 \%$ of the Canadian IPOs. For example, we find a degree of underpricing for the whole sample (common chares, units and JCP IPOs) of $6,7 \%$ on value weighted basis, while it is $73,64 \%$ on equally weighted basis.

${ }^{12}$ Lowry and Schwert (2000) document that the findings that more companies want to go public when IPOs are being underpriced by the greatest amount is puzzling.

${ }^{13}$ In 1998, the gross proceed of Canadian IPOs also decreased. This may be explained by the fact that as the number of going public firms increase in hot period (1997), more information would be available on IPO market and the asymmetric information would decrease. Hence, the initial return of the subsequent year (1998) would decrease.
} 
Zechner (2000) suggest that the clustering of IPOs is explained by the revelation of a common value factor of one firm which serves as a feed-back mechanism to other IPOs ${ }^{14}$.

According to the results of underpricing, we conclude that Canadian capital markets are not doing a good job in allocating capital to entrepreneurs. IPOs are underpriced as well as almost IPOs in different countries. An IPO is new, unseasoned and relatively unknown equity issue. As a result, the general uncertainty of future profitability and the asymmetry of information between issuer and investor are much greater than for conventional issues by listed firms. Moreover, the underpricing is an indirect cost supported by issuers. So a high level of underpricing may limit their access to capital markets. Meanwhile, the degree of underpricing seems related to the type of the issue (units or JCP) as well as to the size, the period and the sector of the issue.

\section{2- Cross-sectional patterns}

We now turn to the cross-sectional analysis of the short-run behaviour of the IPO's. The purpose of this section is to shed some light on the determinants of underpricing. We also examine the relationships between underpricing and the size of the issue, the role of the underwriter and the market climate. A multivariate analysis is reported after the univariate tests.

$* * *$ Table $7 * * *$

Size : the size of the issue has a well-documented relationship with underpricing (Ritter, 1987, Chalk and Peavy, 1990, Jog and Riding, 1987, Suret, Cormier and Lemay, 1990 and Clarkson and Merkley, 1994). Table 7 presents underpricing results for the sample partitioned on the basis of the size of the issue. Our results in table 7 suggest that small IPOs (gross proceeds less than a million dollars) are more underpriced (for example, $\operatorname{UND}(1)=119,07 \%$ and $\operatorname{UND}(2)=124,11 \%$ ) than large IPOs. Moreover, IPOs with gross proceed more than 20 millions dollars are lightly overpriced $(\mathrm{UND}(1)=-1,36 \%$ and $\mathrm{UND}(2)=-0.78 \%)$. However, among the 540 small common shares IPOs, 433 are JCP IPOs which have huge initial returns (UND (1): 135,41\% et UND (2): $140,88 \%)$. The difference on average initial return between the two subgroups is significant at $1 \%$. This confirms the existing evidence, which indicates a high ex-ante uncertainty associated with small offerings. The underpricing would be essentially a small issue's phenomenon. This explain why our results differ from those of previous Canadian Studies (Clarkson and Merkley ${ }^{15}$ (1994) and Jog (1997)). Indeed, in our sample we include all IPOs listed on the four Canadian stock exchanges, which wasn't the case for Clarkson and Merkley and Jog. If we consider only IPOs with gross proceeds between $\$ 10$ millions and $\$ 20$ millions, we find a non adjusted average initial return of 3,6\% (and an adjusted average initial return of 4,28\%).

\footnotetext{
${ }^{14}$ Lowry (2000) shows that the observed fluctuation in IPOs volume are related to three factors: changes in private firms'agregate demand for capital, changes in the adverse selection costs of issuing equity and variation in investor sentiment.

${ }^{15}$ The average gross proceeds in our sample is $\$ 14,65$ millions, and it was $\$ 30,33$ millions in the sample of Clarkson et Merkley (1994).
} 
Industry: when the sample is segmented by industry ${ }^{16}$, we notice that the underpricing of Canadian IPO's varies widely in different industries. For example, mining, real estate, oil and gas and technology IPO's are more underpriced than production and film production IPOs. (respectively, 35,71\%,16,9\%, 29,04\% and 19,77\% versus $11,11 \%$ and 4,05\%). These results confirm the findings of Ritter (1991). A plausible explanation for the technology IPOs is given by Hand (2000). He suggests that since Technology IPO's are generally smaller than the "old economy" IPOs, the supply of shares is very low if compared to the demand, and this may cause high initial returns. Wen (1999) document that investors are willing to buy, in general, "new economy" stocks in order to diversify their portfolios and reduce systematic risk. Arosio, Guidici and Paleari (2000b) point out that huge initial returns of high-tech IPOs are basically explained by three factors : investor's euphoria for the new economy, the quality of the private information and publicly available information from the prospectus.

Continuing, we find that communications and media and merchandising IPO's are overpriced (UND(1) is respectively $-4,66 \%$ and $-1,9 \%$ ) and financial services IPOs lightly underpriced (UND(1) : 1,31\%). The average size of these issues were respectively $\$ 73,78$ millions, $\$ 31,79$ millions and $\$ 32,78$ millions. The same patterns are observed for units IPO and for our entire sample.

Province : when the sample is segmented by province, we notice that Albertan and British Columbian common shares IPOs excluding JCP are more underpriced than Ontarian IPOs (respectively, 26,41\% and 35,95\% versus 11,20\%). This may be explained by the size of the Albertan and British Columbian offerings, which averaged $\$ 15,08$ and $\$ 8,46$ millions respectively. The average size of Ontarian IPOs was $\$ 46,65$ millions. The differences in the listing requirements and other regulatory aspects which are more severe for Ontarian IPOs may affect the degree of underpricing. The majority of Albertan and British Columbian IPOs are from oil and gas and mining industries which are more underpriced than those from other sectors.

On the other hand, the degree of underpricing of Quebecois IPOs are less underpriced than Ontarian IPOs. This result confirms the finding of Suret, Cormier and Lemay (1990). These authors notice that the degree of underpricing for 86 Quebecois IPOs issued under the QSSP program average $-0.32 \%$ and the Ontarian IPOs averaged 12,66\%, during the period between 1979 and 1985. The size of the issue may again explain this difference. The gross proceeds of Quebecois IPOs in our sample is \$2281,5 million.

Underwriter reputation: the value of the underwriter's reputation depends not only on its activity in the IPO market, but on the entire array of activities with which it is involved. Therefore, we use the value of IPOs raised by each underwriter as a leader and a syndicate member to proxy for it's reputation. The "Financial Post" gives us the ranking for the top 25 underwriters, according to this measure. Then, we divide our sample into two groups for prestigious and less prestigious underwriters. Underwriters who figured in the ranking of the "Financial Post" are classified as prestigious. The average underpricing for the sample partitioned

\footnotetext{
${ }^{16}$ Our segmentation by industry is based on the classification of the System for Electronic Document Analysis and Retrieval (SEDAR) available at the following address: www.sedar.com.
} 
on the basis of underwriter reputation, are presented in table 7. For common shares IPOs excluding JCP, we find that the degree of underpricing was $31,13 \%$ ( $\mathrm{UND}(2): 33,16 \%$ ) when the IPO is raised by a non prestigious underwriter and 9,37\% (UND(2) : 10,39\%) when a prestigious underwriter helps the company to go public. The difference between the two groups is significant at $1 \%$ level. These results can be interpreted as follows. The reputation of the underwriter resolves some of the uncertainty about the quality of the IPO. The more the underwriter's prestige, the less risky the IPO is, and the lower the required initial return. Prestigious underwriters avoid the smaller firms for several reasons. First, they are concerned about the reputation of their firms being affected if they begin to participate in the underwriting of smaller firms. Second, the underwriting commission is typically a function of the issue size.

The same pattern was observed for JCP-IPOs and unit IPOs. Continuing, we also find that the difference between the two groups for JCP-IPOs is smaller but significant at $1 \%$ level. This result may be explained by the fact that JCP-IPOs are generally raised by less prestigious underwriters. Indeed, in Alberta, a number of regional brokerage firms have taken advantage of the JCP program to carve out a profitable underwriting and trading niche. MacIntosh (1994) point out that "national investment dealers have shown little interest in serving the IPO market for offerings of less than \$25 million”.

Market climate : average underpricing for the sample partitioned on the basis of market climate $^{17}$, are presented in table 7 . For common shares IPOs excluding JCP, we find that the degree of underpricing was 22,03\% when the IPO market was "hot" and 16,77\% when the IPOmarket was "cold". The difference in average initial returns between hot issues and cold issues is not significant at conventional level. The same pattern is found, for units-IPOs and JCP-IPOs. The degree of underpricing when the IPO market was "hot" average 48,02\% and 142,7\%, respectively. While, The degree of underpricing when the IPO market was "cold" average $22,49 \%$ and $122,84 \%$, respectively. As confirmed by previous studies, the market climate may lead the decision to go public for many issues. Investors, on the other hand, are willing to compensate underwriters indirectly in order to gain favourable allocations on hot deals, by paying above the offer price. Loughran and Ritter (2001) document that issuers care about the change in their wealth, rather then the level of wealth and they don't bargain hard for an offer price increase when the market goes up. However, Loughran and Ritter's application of prospect theory can not explain why issuers choose underwriters with a history of severe underpricing. The relationship between the degree of underpricing and hot issues market is still a puzzle.

It seems difficult to separate the four effects analysed in this section: the size, the choice of the underwriter and the industry are related, the industry segmentation is not the same for all the provinces and the market climate may vary across sectors. It seems important then to conduct a multivariate analysis.

\footnotetext{
${ }^{17}$ Taking into account the results of the previous section, we consider 1993, 1994, 1996 and 1997 as hot periods and 1991, 1992, 1995 and 1998 as cold periods.
} 


\subsection{Multivariate analysis}

Results of the multivariate regression model presented in table 8 generally serve to narrow and refine the basic conclusions drawn from the univariate tests reported in table 7 . The regression model has the following form ${ }^{18}$ :

$\mathrm{UND}_{\mathrm{i}}=\alpha_{0}+\alpha_{1} \mathrm{O} \& \mathrm{G}_{\mathrm{i}}+\alpha_{2} \mathrm{MINING}_{\mathrm{i}}+\alpha_{3} \mathrm{~T}_{\mathrm{i}}+\alpha_{4} \mathrm{JCP}_{\mathrm{i}}+\alpha_{5} \log (\text { Proceeds })_{\mathrm{i}}+\alpha_{6} \mathrm{MC}_{\mathrm{i}}+\alpha_{7} \mathrm{PU}_{\mathrm{i}}+\varepsilon_{\mathrm{i}}$

where $\mathbf{U N D}_{\mathbf{i}}$ is the degree of underpricing of the stock $\mathbf{i}, \mathbf{O \& G}$ takes a value of 1 for oil and gas issues and zero otherwise, MINING takes a value of 1 for mining issues and zero otherwise, T takes a value of 1 for technology issues and zero otherwise, JCP takes a value of 1 for junior capital pool issues and zero otherwise, $\mathbf{M C}$ is the market climate variable which takes a value of 1 for hot period and zero for cold period, PU takes a value of 1 for a participation of a prestigious underwriter in the IPO and 0 otherwise and Log denotes the natural logarithm. The proceed of the issue is used as a proxy for ex-ante uncertainty.

First, the JCP variable is treated as a dummy variable. However, a detection of a significant effect would not allow us to conclude definitely, as we don't know if the difference is due to the constant or to the independent variables. An effect on the constant would mean that JCP has an effect on the average underpricing, while an effect on the coefficients would suggest that the independent variables affect the dependant variable differently as the IPO is JCP or not. Second, we use Johnston's (1986) structural adjustment methods to analyse the behaviour of the JCP variable.

Thus, we use the three following models :

\section{Model 1}

$\mathrm{UND}_{\mathrm{i}}=\alpha_{0}+\alpha_{1} \mathrm{O} \& \mathrm{G}_{\mathrm{i}}+\alpha_{2} \mathrm{MINING}_{\mathrm{i}}+\alpha_{3} \mathrm{~T}_{\mathrm{i}}+\alpha_{4} \log (\text { proceeds })_{\mathrm{i}}+\alpha_{5} \mathrm{MC}_{\mathrm{i}}+\alpha_{6} \mathrm{PU}_{\mathrm{i}}+\varepsilon_{\mathrm{i}}$

\section{Model 2}

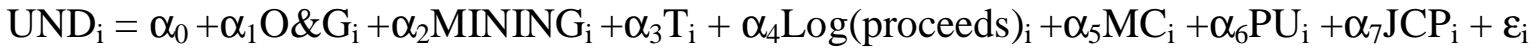

\section{Model 3}

$$
\begin{aligned}
& \mathrm{UND}_{\mathrm{i}}=\alpha_{0}+\alpha_{1} \mathrm{O} \& \mathrm{G}_{\mathrm{i}}+\alpha_{2} \mathrm{MINING}_{\mathrm{i}}+\alpha_{3} \mathrm{~T}_{\mathrm{i}}+\alpha_{4} \log (\text { proceeds })_{\mathrm{i}}+\alpha_{5} \mathrm{MC}_{\mathrm{i}}+\alpha_{6} \mathrm{PU}_{\mathrm{i}}+\alpha_{7} \mathrm{JCP}_{\mathrm{i}}+ \\
& \alpha_{8} \mathrm{JCP} \mathrm{O} \& \mathrm{G}_{\mathrm{i}}+\alpha_{9} \mathrm{JCP} \times \mathrm{MINING}_{\mathrm{i}}+\alpha_{10} \mathrm{JCP} \times \mathrm{T}_{\mathrm{i}}+\alpha_{11} \mathrm{JCP} \times \log (\text { proceeds })_{\mathrm{i}}+\alpha_{12} \mathrm{JCP} \times \mathrm{MC}_{\mathrm{i}} \\
& +\alpha_{13} \mathrm{JCP} \times \mathrm{PU} \mathrm{U}_{\mathrm{i}}+\varepsilon_{\mathrm{i}}
\end{aligned}
$$

For each model, we isolate the squared sum of the residuals (SSR). Then, we test the three following hypotheses :

The equality of the constants hypothesis (model 1 is confronted to model 2) :

$\mathrm{F}=\frac{\mathrm{SCR}_{1}-\mathrm{SCR}_{2}}{\mathrm{SCR}_{2} /(\mathrm{n}-\mathrm{k}-1)} \quad \sim \mathrm{F}(1, \mathrm{n}-\mathrm{k}-1)$

\footnotetext{
${ }^{18}$ We run the same regression including a dummy variable for unit IPOs. This doesn't change significantly the results presented hereafter.
} 
The equality of the coefficients hypothesis (model 2 is confronted to model 3) :

$\mathrm{F}=\frac{\mathrm{SCR}_{2}-\mathrm{SCR}_{3} /(\mathrm{k}-1)}{\mathrm{SCR}_{3} /(\mathrm{n}-2 \mathrm{k})} \sim \mathrm{F}(\mathrm{k}-1, \mathrm{n}-2 \mathrm{k})$

The equality of the regression's line hypothesis (model 1 is confronted to model 3) :

$\mathrm{F}=\frac{\mathrm{SCR}_{1}-\mathrm{SCR}_{3} / \mathrm{k}}{\mathrm{SCR}_{3} /(\mathrm{n}-2 \mathrm{k})} \quad \sim \mathrm{F}(\mathrm{k}, \mathrm{n}-2 \mathrm{k})$

$* * *$ Table $8 * * *$

We estimate the equation (13) for all Canadian IPOs using the ordinary least squares method. The results are presented in table 8 and are corrected for heteroscedasticity using the adjustment procedure of White (1980). The results indicate that the seven explanatory variables identified earlier taken together explain $16,74 \%$ of the variation in the initial return of Canadian IPOs (UND(1) and $15,51 \%$ of the variation in $\operatorname{UND}(2)$.

At first glance, it becomes evident that there is a high statistically significant negative relationship between the underpricing and the proceeds. This result is consistent with the findings of previous studies and confirms the fact that the greater is the ex-ante uncertainty about a value of an issue, the greater is the expected underpricing (Beatty and Ritter, 1986) ${ }^{19}$.

Another variable playing a significant role in explaining the initial excess return of Canadian IPOs is the market climate. Consistent with Ritter (1998), Derrien and Womack (2000) and Arosio, Guidici and Paleari (2000b), this variable has a significant positive impact on the degree of underpricing. As discussed earlier, this could be due to the fact that in hot markets, investors may be overly optimistic about a firm's prospects, causing the aftermarket equilibrium price to be greater than in normal conditions. Hence, the degree of underpricing would be high during these periods.

The fourth variable included in the model is the reputation of the underwriters. The empirical literature, as discussed earlier, suggests that this variable should be inversely related to the underpricing level. We find that this relation is negative but not significant. The low participation of prestigious underwriters may explain this result. Obviously, Canadian large underwriting firms avoid smaller firms because they are concerned about their reputation being affected if they begin to participate in the underwriting of smaller firms ${ }^{20}$. For example, the average proceeds for common shares IPOs (excluding JCP) underwritten by prestigious underwriters was $\$ 52,48$ millions while it was $\$ 14,5$ millions for IPOs underwritten by low prestigious underwriters.

The coefficients of the mines, technology and oil and gas sectors are positive but not significant. Technology IPOs is treacherous to evaluate which may explain the high level of underpricing. Ritter (1991) also confirms that mines and oil and gas IPOs are more underpriced than those from other sectors.

\footnotetext{
${ }^{19}$ Also, Katz and Owen (1987) point out that «Thus, as information sets diverge, we would expect increased underpricing».

${ }^{20}$ This situation create a gap in the availability of public equity of less than $\$ 1$ million for Ontarian small firms, which can not be listed on the Toronto Stock Exchange.
} 
The coefficient of the JCP variable is significant and positive at $1 \%$ level. As expected, common shares IPOs are less underpriced than JCP IPOs. Then, this result remain unchanged after controlling for the size, the role of the underwriter, the three sectors considered and the market climate.

The squared sum of the residuals for the three models are respectively 1657.10, 1608.16 and 1597.27 (when UND (1) is a dependent variable) ${ }^{21}$. We reject the equality of the constants and the equality of the regression's line hypotheses at $1 \%$ level $\left(F_{1,963}=29,29 ; F_{7,957}=5,12\right)$. However, we can not reject the equality of the coefficients hypothesis at $1 \%$ level $\left(\mathrm{F}_{6,957}=\right.$ 1,087). Thus, the impact of the coefficients of the independent variables on the degree of underpricing is the same whether the IPO is a JCP or not. On the other hand, the significant effect on the constant allow us to confirm that JCP affect the degree of underpricing.

One possible explanation for the huge underpricing of JCP IPOs is that these issues are typically risky. Furthermore, as discussed earlier, the JCP program was transitory and a JCP firm had a limit of 18 months in which to complete a major transaction or it was delisted. So, this time limit increase the risk of the JCP IPO.

The results of the multivariate analysis served to reinforce but narrow the basic conclusions drawn from the univariate analysis. We find that ex-ante uncertainty and market climate are important determinants to explain the underpricing phenomenon in Canada. The results of the structural adjustment tests show that junior stocks IPOs are more underpriced than non junior stocks IPOs.

\section{Conclusions}

This study has examined the relation between the degree of underpricing, for a wide sample of 971 Canadian IPOs, and ex ante uncertainty, from the period 1991-1998. The average initial return for common shares IPOs (excluding JCP) was 20,57\% (22,57\% with a market adjusted measure). Thus, there appears to be no major difference between the degree of underpricing of Canadian IPOs and previous international evidence but our results are different to those of previous Canadian studies. However, the degree of underpricing depends on the type of the issue. Unit IPOs and JCP IPOs are more underpriced than common shares IPOs.

Results of our univariate analysis, for the most part, are consistent with previous empirical research based on US IPO data. Specifically, we find that underpricing decreased with the size of the issue and the prestige of the underwriter. We also find that mining, oil and gas, real estate and technology IPOs are more underpriced than those from other sector. Interestingly, we find that Albertan and British Columbia IPOs are more underpriced than Ontarian IPOs. This result may be explained by the experience of large firms who are listed on the Toronto Stock Exchange.

We have entertained a number of possible explanations for the high initial return of Canadian issuing firms. We find that underpricing is significantly related to the size and the period of the

\footnotetext{
${ }^{21}$ The results of the structural adjustment test remain unchanged with $\mathrm{UND}(2)$ as a dependant variable.
} 
issue and to whether the IPO is a JCP or not. On the other hand, the prestige of the underwriter is positively related to the underpricing but this relationship is not significant.

One important aspect of a firm's decision to go public is that of receiving a proper price for its common shares. If IPOs are significantly underpriced, many eligible firms would become reluctant to choose an IPO as a means of raising equity capital. Our study shows that the IPO market in Canada is «good» only for large offerings. 


\section{References}

Affleck-Graves, J., Hegde, S., Miller, R., « Conditional price trends in the aftermarket for initial public offerings », Financial Management 25, p. 25-40, 1996.

Aggarwal, R., «Stabilization activities by underwriters after initial public offerings », Journal of Finance 55, p. 1075-1103, 2000.

Aggarwal, R., Leal, R., Hernandez, F., « The aftermarket performance of initial public offerings in Latin America », Financial Management 22, p. 42-53, 1993

Aggarwal, R., Rivoli, P., «Fads in the initial public offering market ? », Financial Management 19, p. 45-57, 1990.

Allen, F., Faulhaber, G.R., «Signalling by underpricing in the IPO market», Journal of financial Economics 23, p. 303-323, 1989.

Arosio, R., Guidici, G., Paleari, S., «Why do (or did ?) internet-stock IPOs leave so much "money on the table"? », SSRN working paper (a), 2000.

Arosio, R., Guidici, G., Paleari, S., «What drives the initial market performance of Italian IPOs ? An empirical investigation on underpricing and price support », SSRN working paper (b), 2000.

Aussenegg, Wolfgang, «Short and long-run performance of Initial Public Offerings in the Austrian Stock Market », Vienna University of Technology working paper, 1997.

Barber, B., Lyon, J., «Detecting abnormal operating performance : The empirical power and specification of test statistics », Journal of Finance 41, p. 359-399, 1996.

Barber, B., Lyon, J., «Detecting long-run abnormal stock returns: the empirical power and specification of test statistics », Journal of Financial Economics 43, p. 341-372, 1997.

Barber, B., Lyon, J., «How can long-run abnormal stock returns be both positively and negatively biased?», SSRN working paper, 1998,

Baron, D., «A model of the demand for investment banking advising and distribution services for new issues », Journal of Finance 37, p. 955-976, 1982.

Barry, C., Jennings, R., «The opening price performance of initial public offerings of common stock », Financial Management 22, 54-63, 1993.

Barry, C., Muscarella, C., Peavy, J., Vetsuypens, M., «The role of venture capital in the creation of a public company », Journal of Financial Economics 27, p. 447-471, 1990.

Beatty, R., Ritter, J., «Investment banking, reputation and the underpricing of initial public offerings », Journal of Financial Economics 15, p. 213-232, 1986.

Beatty, R., Welch, I., « Issuer expenses and legal liability in initial public offerings », Journal of Law and Economics 39, p. 545-602, 1996.

Bommel, V., Vermaelen, T., «Market feedback during initial public offering: Do managers listen ? », INSEAD working paper, 2000. 
Brav, A., Gompers, P., «Myth or reality? The long-run underperformance of initial public offerings: Evidence from venture and non venture capital-backed companies », Journal of Finance 52, p. 1791-1821, 1997.

Brean, D., «The climate for initial public offerings in Canada », Financing Growth in Canada ed. P. Halpern, University of Calgary press, p. 706-708, 1997.

Buser, S., Chan, K., «NASDAQ/NMS Qualification stand, Ohio registration experience and the price performance of initial public offerings », Ohio Department of Commerce and national Association of Securities Dealers Inc, Columbus, 1987.

Cai, M., Shi, S., «Publicity and the clustering of IPO underpricing», working paper Queen's University, 1999.

Carter, R., Dark, F., Singh, A., «Underwriter reputation, initial returns, and the long-run performance of IPO stocks », Journal of Finance 53-1, p. 285-311, 1998.

Carter, R., Manaster, S., «Initial public offerings and underwriter Reputation», Journal of Finance 45, p. 1045-1068, 1990.

Chalk, A., Peavy, J., «Initial public offerings: Daily returns, offering types and the price effect», Financial Analyst Journal 43-5, p. 65-69, 1987.

Chalk, A., Peavy, J., "Understanding the pricing of initial public offerings », Research in Finance 8, p. 203-240, 1990.

Chan, A., Pan. K., «An answer to the long-run performance puzzle of IPOs in Taiwan: An application of the Fama-French model », National Sun Yat-Sen University working paper, 1998.

Clarkson, P., Merkley, J., «Ex ante uncertainty and the underpricing of initial public offering: Further Canadian evidence », Canadian Journal of Administrative Sciences 11, p. 54-67, 1994.

Chowdhry, B., Sherman, A., «The winner's curse and international methods of allocating initial public offerings », Pacific-Basin Finance Journal 4, p. 15-30, 1996.

Derrien, F., Womack, K., « Auctions vs book-building and the control of underpricing in hot markets », Dartmouth working paper, 2000.

De Bondt, W., Thaler, R., «Does the stock market overreact? », Journal of Finance 40, p. 793 808, 1985.

Dewenter, K., Malatesta, P., « Public offerings of state-owned and privately-owned enterprises: An international comparison», Journal of Finance, Vol. III, No. 4, p. 1659-1679, 1997.

Dimson, E., « Risk measurement when shares are subject to infrequent trading », Journal of Financial Economics 7, p. 197-226, 1979.

Eijgenhuijsen, H., Buijs, A., «Initial public offerings in the Netherlands 1982-1991 », University of Amsterdam working paper, 1993. 
Falk, H., Thornton, D., «The Canadian market for initial public offerings: Evidence from the Toronto, Montreal and Alberta stock exchanges », Unpublished working paper, 1992.

Fama, E., « Market efficiency, long-term returns, and behavioral finance » Journal of Financial Economics 49, p. 283-306, 1998.

Field, L., «Is institutional investment in initial public offerings related to long-run performance of these firms? », Pennsylvania State University working paper, 1995.

Firth, M., «An analysis of the stock market performance of new issues in New Zealand», Pacific-Basin Finance Journal 5, p. 63-85, 1997.

Friedlan J., Maynes, E., Verma, S., «The Long Run Performance of Canadian Initial Public Offerings », Schulisch School of Business, York University working paper, 1994.

Giudici, G, Paleari, S., «Underpricing, price stabilization and long run performance in initial public offerings: as study on the Italian stock market between 1985 and 1998 », SSRN working paper, 1999.

Habib, M., Ljungqvist, A., «Underpricing and entrepreneurial losses in IPOs: Theory and evidence », SSRN working paper, 1999.

Hand, J., «Profits, losses and the non-linear pricing of internet stocks », SSRN working paper, 2000.

Hebner, K., Hiraki, T., «Japanese initial public offerings », Restructuring Japan's Financial Markets, edition Walter. I et Hiraki. T Homewood, IL: Business One/Irwin.1993.

Helwege, J., Liang, N., « Initial public offerings in hot and cold markets », Federal Reserve Bank of New York, 1996.

Holhausen, R., Larcker, D., «The financial performance of reverse leveraged buyouts », Journal of Financial Economics 42, p. 293-332, 1996.

How, J., Izan, H., Monroe, G., «Differential information and the underpricing of initial public offerings: Australian evidence», Accounting and Finance vol. 35 (1), p. 87 -106, 1995.

How, J., Howe, J., «Warrants in initial public offerings: Empirical evidence », The Journal of Business vol 74 (3), forthcoming 2001.

Hoffmann-Burchardi, U., «Clustering of initial public offerings, information revelation and underpricing », European Economic Review 45, p. 353-383, 2001.

Huang, Q., Levich, R., « Underpricing of new equity offerings by privatized firms: An international test», SSRN working paper, 1998.

Ibbotson, R., «Price performance of common stock new issues », Journal of Financial Economics 2, p. 235-272, 1975.

Ibbotson, R., Jaffe, J., «Hot issue markets», Journal of Finance, Vol XXX (4), p. 1027-1042, 1975. 
Ibbotson, R., Sindelar, J., Ritter, J. «The market's problems with the pricing of initial public offerings », Journal of Applied Corporate Finance 7, 66-74, 1994.

Jog, V., Srivastava, A., «Underpricing in Canadian IPOs 1971-1992-- An update », FINECO 4, No. 1, p. 81-87, 1994.

Jog, V., «The climate for Canadian initial public offerings », Financing Growth in Canada, ed. P. Halpern, University of Calgary press, p. 357-401, 1997.

Jog, V., McConnomy, B., «Voluntary disclosure of management earnings forecasts in IPOs and the impact on underpricing and post - issue return performance», SSRN working paper, 1999.

Jog, V., Riding, A., «Underpricing in Canadian IPOs », Financial Analysts Journal, p. 45-55, 1987.

Johnston, J., Méthodes économétriques (third edition), Paris :Economica, 1985.

Katz, G., Owen, J., « Initial public offering: an equilibrium model of price determination», Journal of Economics, Auditing \& Finance, p. 266-284, 1987.

Katsuna, K., Smith, R., «How IPO pricing method affects underpricing and issue cost: Evidence on Japan's change from auction method pricing to book-building », SSRN working paper, 2000.

Keloharju, M., «The winner's curse, legal liability, and the long-run price performance of initial public offerings in the Finland », Journal of Financial Economics 34, p. 251-277, 1993.

Kim, J., Krinsky, I., Lee, J., « The aftermarket performance of initial public offerings in Korea», Pacific-Basin Finance Journal 3, p. 429-448, 1995.

Kim, M., Ritter, J., « Valuing IPOs », Journal of Financial Economics 53:3, p. 409-437 1999.

Kothari, S., Warner, J., «Measuring long-horizon security price performance », Journal of Financial Economics 43, p. 301-339, 1997.

Krigman, L., Shaw, W., Womack, K., «The persistence of IPO mispricing and the predictive power of flipping », Dartmouth College working paper, 1997.

Lee, J., Henderson, G., «The hot issue market phenomenon and business conditions », University of Cincinnati working paper, 1999.

Lee, P., Taylor, S., Walter, T., «Australian IPO pricing in the short and long run », Journal of Banking \& Finance 20, p. 1189-1210, 1996.

Lee, M., Lee, P., Taylor, S., «Unit initial public offerings: Staged equity or signalling mechanism ? », SSRN working paper, 2000.

Liaw, G., Liu, Y., Wei. K., « On the demand elasticity of initial public offerings: An analysis of discriminatory auctions», Hong Kong University of Science and Technology working paper, 2000. 
Lerner, J., «Venture capitalists and the decision to go public », Journal of Financial Economics 35, p. 293-316, 1994.

Levis, M., «The long-run performance of initial public offerings: The UK experience 1980$1988 »$, Financial Management 22, 28-41,1993.

Ljungqvist, A., «IPO underpricing, wealth losses and the curious role of venture capitalists in the creation of public companies », SSRN working paper, 1999.

Ljungqvist, A., «Pricing initial public offerings : Further evidence from Germany », European Economic Review 41, p. 1309-1320, 1997.

Ljungqvist, A, Jenkinson, T., Wilhelm, W., «Global integration in primary equity markets: The role of U.S. banks and U.S. investors » NYU working paper, 2000.

Loughran, T., Ritter, J., «The new issues puzzle », Journal of Finance 50, p. 23-51, 1995.

Loughran, T., Ritter, J., «Uniformly least powerful tests of market efficiency », Unpublished manuscript, University of Florida, 1998.

Loughran, T., Ritter, J., «Why don't issuers get upset about leaving money on the table in IPOs ? », Review of Financial Studies, forthcoming 2001.

Loughran, T., Ritter, J., Rydqvist, K., «Initial public offerings: International insights », PacificBasin Finance Journal 2, p. 165-199, 1994.

Lowry, M., « Determinants of IPO volume », Pen State University working paper, 2000.

Lowry, M., Schwert, G., «IPO market cycles: an explanatory investigation », SSRN working paper, 2000.

Lowry, M., Schwert, G., « Biases in the IPO pricing process », NBER working paper, 2001.

Lyon, J., Barber, B., Tsai, C., «Improved methods for tests of long-run abnormal stock returns », Journal of Finance 54, p. 165-201, 1999.

MacIntosh, J., «Legal and institutional barriers to financing innovative enterprise in Canada», Queen's University working paper, 1994.

MacIntosh, J., «Les sorties du marché du capital de risque au Canada et aux États-Unis », Industrie Canada working paper, University of Galgary press, 1997.

Maksimovic, V., Unal, H., «Issue size choice and underpricing in thrift mutual-to-stock conversions », Journal of Finance 48, p. 1659-1692, 1993.

Mathias, P., «Police, regulators, losing the fight as stock fraud runs rampant », The Financial Post, p. 10-11, 1994.

McGuinness, P., «An examination of the underpricing of initial public offerings in Hong Kong », Journal of Business Finance and Accounting 19, p. 165-186, 1992.

Michaely, R., Shaw, W., «The pricing of initial public offerings: Tests of adverse selection and signalling theories », The Review of Financial Studies 7, p. 279-319, 1994. 
Mikkelson, W., Partch, M., Shah, K., «Ownership and operating performance of companies that go public », Journal of Financial Economics 44, p. 281-307, 1997.

Mok, H., Hui, Y., « Underpricing and aftermarket performance of IPOs in Shanghai, China », Pacific-Basin Finance Journal 6, p. 453-474, 1998.

Pagano, M, Panetta, F., Zingales, L., «The stock as a source of capital : Some lessons from initial offerings in Italy », European Economic Review 40, p. 1057-1069, 1996.

Pagano, M., Panetta, F., Zingales, L., «Why do companies go public ? An empirical analysis », Journal of Finance 53-1, p. 27-64, 1998.

Paudyal. K., Saadouni, B., Briston, R., «Privatisation initial public offerings in Malaysia: Initial premium and long-term performance», Pacific-Basin Finance Journal 6, p. 427-451, 1998.

Rajan, R., Servaes, H., «Analyst following of initial public offerings », Journal of Finance 52, p. 507-529, 1997.

Reese, W., «IPO underpricing, trading volume, and investor interest», SSRN working paper, août 1998.

Ritter, J., «Initial public offerings», Contemporary Finance Digest, Vol. 2, No. 1, p. 5-30, 1998.

Ritter, J., « The hot issue market of $1980 »$, Journal of Business 32, p. 215-240, 1984.

Ritter, J., «The long-run performance of initial public offerings », Journal of Finance 46, p. 327, 1991.

Ritter, J., «The long-run performance of initial public offerings », Journal of Finance 46, p. 327, 1991.

Ritter, J., « The costs of going public », Journal of Financial Economics 19, p. 269-281, 1987.

Ritter, J., «Investment Banking and Securities Issuance», chapitre $9 \mathrm{du}$ North-Holland Handbook of the Economics of Finance, ed. George Constantinides, Milton Harris et René Stulz, (à paraître 2002), version 7 mars 2001.

Robinson, M., «Mobiliser des capitaux d'investissement pour les petites et moyennes entreprises sur les marchés boursiers au Canada », Financing Growth in Canada, ed. P. Halpern, University of Calgary press, p. 659-709, 1997.

Rock, K., «Why new issues are underpriced », Journal of Financial Economics 15, p. 187-212, 1986.

Rydqvist, K., Häogholm, K., «Going public in the 1980s: evidence from Sweden », European Financial Management 1, p. 287-315, 1995.

Sherman, A., «Global trends in IPO methods: Book-building vs. auctions», Notre Dame University working paper, 2001.

Schultz, P., «Unit initial public offerings-A form of staged financing », Journal of Financial Economics 15, p. 187-212, 1993. 
Shiller, R., « Do stock prices move too much to be justified by subsequent changes in dividend?», American Economics Review, p. 421-436, 1981.

Stoughton, N., Wong, K., Zechner, J., «IPO and product quality », Journal of Business 74, no 3, 2001.

Su, D., Fleisher, B., «An empirical investigation of underpricing in Chinese IPOs », PacificBasin Finance Journal 7, p. 173-202, 1999.

Suret, J., Cormier, E., Lemay, B., «Le RÉAQ et la sous-évaluation initiale du prix des titres», Canadian Journal of Administrative Sciences 7, No. 3, p. 47-56, 1990.

Teoh, S., Welch, I., Wong, T., «Earnings management and the post-issue underperformance in seasoned equity offerings », Journal of Financial Economics 50, p. 63-99, 1998.

Teoh, S., Welch, I., Wong, T., «Earnings management and the long-run market performance of initial public offerings », Journal of Finance 53, p. 1935-1974, 1998.

Tinic, S., « Anatomy of initial public offering of common stock », Journal of Finance 43, p. 789$822,1988$.

Titman, S., Trueman, B., «Information quality and the valuation of new issues », Journal of Accounting and Economics 8, p. 159-172, 1986.

Welch, I., « Seasoned offerings, imitation costs and the underpricing of initial public offerings », Journal of Finance 44, p. 421-449, 1989.

Wen, K., «Residual risk, investor heterogeneity, and participation restriction: Explaining longrun underperformance of initial public offerings », SSRN working paper, 1999.

White, H., «A Heteroscedasticity-Consistent Covariance Matrix Estimator and a Direct Test for Heteroscedasticity », Econometrica, 48, p. 817-838, 1980. 


\section{Table 1}

Results of previous studies. The sample consists of 971 Canadian IPOs by firms subsequently listed on the Toronto Stock Exchange, the Montreal Exchange, the Vancouver Exchange and the Alberta Exchange, from January 1991 through December 1998. We included Junior Capital Pool IPOs. The degree of underpricing is given by : (mean closing price of the five first days of listingoffer price)/ offer price.

\begin{tabular}{|c|c|c|c|c|}
\hline Country & Author & Number & Period & $\begin{array}{l}\text { Average initial } \\
\text { return }\end{array}$ \\
\hline Germany & Ljungqvist & 170 & $1978-92$ & $10,9 \%$ \\
\hline Australia & Lee, Taylor \& Walter & 266 & $1976-89$ & $11,9 \%$ \\
\hline Austria & Aussenegg & 67 & $1964-96$ & $6,5 \%$ \\
\hline Brazil & $\begin{array}{l}\text { Aggarwal, Leal \& } \\
\text { Hernandez }\end{array}$ & 62 & $1980-90$ & $78,5 \%$ \\
\hline Canada & $\begin{array}{l}\text { Jog } \\
\text { Our sample }\end{array}$ & $\begin{array}{l}383 \\
758\end{array}$ & $\begin{array}{l}1971-94 \\
1991-98\end{array}$ & $\begin{array}{c}8,43 \% \\
28,72 \%\end{array}$ \\
\hline Chilli & $\begin{array}{l}\text { Aggarwal, Leal \& } \\
\text { Hernandez }\end{array}$ & 19 & $1982-90$ & $16,3 \%$ \\
\hline China & Su and Fleisher & 308 & $1987-95$ & $948,5 \%$ \\
\hline United States & Ritter & 13,308 & $1960-96$ & $15,8 \%$ \\
\hline Finland & Keloharju & 85 & 1984-92 & $9,6 \%$ \\
\hline France & Derrien \& Womack & 264 & $1992-98$ & $13,2 \%$ \\
\hline Hong Kong & McGuinness & 334 & $1980-96$ & $15,9 \%$ \\
\hline Italy & Giudici \& Paleari & 135 & $1985-98$ & $23,9 \%$ \\
\hline Japan & Hebner \& Hiraki & 472 & $1970-91$ & $32,5 \%$ \\
\hline Malaysia & $\begin{array}{l}\text { Paudyal, Saadouni \& } \\
\text { Briston }\end{array}$ & 95 & 1984-95 & $61,8 \%$ \\
\hline Mexico & $\begin{array}{l}\text { Aggarwal, Leal \& } \\
\text { Hernandez }\end{array}$ & 37 & $1987-90$ & $33,0 \%$ \\
\hline New Zealand & Firth & 149 & $1979-87$ & $25,8 \%$ \\
\hline Holland & Eijgenhuijsen \& Buijs & 72 & $1982-91$ & $7,2 \%$ \\
\hline United Kingdom & Levis & 2,133 & $1959-90$ & $12,0 \%$ \\
\hline Singapore & Lee, Taylor \& Walter & 128 & $1973-92$ & $31,4 \%$ \\
\hline Suede & Rydqvist & 251 & $1980-94$ & $34,1 \%$ \\
\hline
\end{tabular}




\section{Table 2}

Results of previous studies by methodology used to measure the degree of underpricing. The degree of underpricing is given by: UND (1) : (mean closing price of the first day of listing- offer price)/ offer price ; UND(2) : [(closing price of the first day of listing offer price)/ offer price] - [price of the market index for the first day of listing - market index price when offer price is fixed)/ market index price when offer price is fixed; $U N D(3): A R_{i t}=R_{i t}-R_{m t}$, where $R_{i t}$ and $R_{m t}$ are respectively, the return of firm $i$ and the return of the matching firm at day $t$ and $U N D(4):\left[(\text { closing price of the first day of listing - offer price)/ offer price] - (beta of firm } i)^{*}\right.$ [price of the market index for the first day of listing - market index price when offer price is fixed)/ market index price when offer price is fixed ].

\begin{tabular}{|c|c|c|c|c|c|}
\hline Author & Country & Underpricing measure & Period & Number & Journal \\
\hline $\begin{array}{l}\text { Affleck-Graves, Hegde and } \\
\text { Miller (1996) }\end{array}$ & United States & $\begin{array}{l}\mathrm{UND}(1)=10,99 \% \\
\mathrm{UND}(2)=10,91 \% \\
\mathrm{UND}(3)=10,66 \%\end{array}$ & $1975-1985$ & 1183 & Financial Management \\
\hline Aggarwal and Rivoli (1990) & United States & $\mathrm{UND}(2)=10,67 \%$ & 1977-1987 & 1598 & Financial Management \\
\hline Clarkson and Merkley (1994) & Canada & $\mathrm{UND}(1)=6,44 \%$ & 1984-1987 & 180 & $\begin{array}{l}\text { Canadian Journal of } \\
\text { Administrative Sciences }\end{array}$ \\
\hline Derrien and Womack (2000) & France & $\mathrm{UND}(1)=13,23 \%$ & 1992- 1998 & 264 & SSRN Working paper \\
\hline Dongwei and Fleisher (1999) & China & UND(1)=948,5\% ( A-shares) & 1987-1995 & 308 & $\begin{array}{l}\text { Pacific_Basin Finance } \\
\text { Journal }\end{array}$ \\
\hline Mok and Hui (1998) & China & $\begin{array}{l}\mathrm{UND}(1)=362,3 \%(\text { A-shares }) \\
\mathrm{UND}(2)=289,2 \% \text { (A-shares) } \\
\mathrm{UND}(1)=24,9 \% \text { (B-shares) } \\
\mathrm{UND}(2)=26 \% \text { ( B-shares) }\end{array}$ & 1990-1993 & 101 & $\begin{array}{l}\text { Pacific_Basin Finance } \\
\text { Journal }\end{array}$ \\
\hline Firth (1997) & New Zealand & $\mathrm{UND}(2)=25,87 \%$ & 1979-1987 & 143 & $\begin{array}{l}\text { Pacific-Basin Finance } \\
\text { Journal }\end{array}$ \\
\hline Guidici and Paleari (1999) & Italy & $\begin{array}{l}\mathrm{UND}(1)=23,87 \% \\
\mathrm{UND}(2)=20,33 \%\end{array}$ & $1985-1987$ & 135 & SSRN Working paper \\
\hline Kim, Krinsky and Lee (1995) & Korea & $\mathrm{UND}(2)=57,56 \%$ & 1985-1989 & 169 & $\begin{array}{l}\text { Pacific-Basin Finance } \\
\text { Journal }\end{array}$ \\
\hline
\end{tabular}


Table 2 (cont'd)

\begin{tabular}{|c|c|c|c|c|c|}
\hline Author & Country & Underpricing measure & Period & Number & Journal \\
\hline Lee, Taylor and Walter (1996) & Australia & $\begin{array}{l}\mathrm{UND}(1)=16,41 \% \\
\mathrm{UND}(2)=11,86 \%\end{array}$ & 1976-1989 & 266 & $\begin{array}{l}\text { Journal of Banking \& } \\
\text { Finance }\end{array}$ \\
\hline Levis (1993) & United Kingdom & $\operatorname{UND}(2)=14,30 \%$ & 1980-1988 & 712 & Financial Management \\
\hline Ljungqvist (1997) & Germany & $\mathrm{UND}(2)=10,57 \%$ & 1987-1991 & 189 & $\begin{array}{l}\text { European Economic } \\
\text { Review }\end{array}$ \\
\hline $\begin{array}{l}\text { Paudyal, Saadouni and Briston } \\
\text { (1998) }\end{array}$ & Malaysia & $\begin{array}{l}\mathrm{UND}(1)=61,8 \% \\
\mathrm{UND}(2)=62,1 \%\end{array}$ & 1995-1995 & 95 & $\begin{array}{l}\text { Pacific_Basin Finance } \\
\text { Journal }\end{array}$ \\
\hline Ritter (1991) & United States & $\mathrm{UND}(3)=14,06 \%$ & 1975-1984 & 1526 & Journal of Finance \\
\hline Suret, Cormier and Lemay (1990) & Canada & $\mathrm{UND}(4)=12 \%$ & $1979-1985$ & 86 & $\begin{array}{l}\text { Canadian Journal of } \\
\text { Administrative Sciences }\end{array}$ \\
\hline
\end{tabular}


Table 3

Distribution of IPO's by year. The sample consists of 971 Canadian IPOs by firms subsequently listed on the Toronto Stock Exchange, the Montreal Exchange, the Vancouver Exchange and the Alberta Exchange, from January 1991 through December 1998. We included Junior Capital Pool IPOs.

\begin{tabular}{ccccccc}
\hline \hline Year & $\begin{array}{c}\text { Common } \\
\text { shares IPOs }\end{array}$ & $\begin{array}{c}\text { Gross proceed } \\
(\$ \text { millions })\end{array}$ & Unit IPOs & $\begin{array}{c}\text { Gross proceed } \\
(\$ \text { millions })\end{array}$ & $\begin{array}{c}\text { Full sample } \\
\text { Gross proceed } \\
\text { (\$ millions) }\end{array}$ \\
\hline 1991 & 13 & $\$ 1045$ & 6 & $\$ 100,5$ & 19 & $\$ 1145,5$ \\
1992 & 33 & $\$ 1439,4$ & 5 & $\$ 43,2$ & 38 & $\$ 1482,7$ \\
1993 & 133 & $\$ 2657,94$ & 14 & $\$ 149,2$ & 147 & $\$ 2807,1$ \\
1994 & 125 & $\$ 2220,6$ & 16 & $\$ 40$ & 141 & $\$ 2260,7$ \\
1995 & 93 & $\$ 456$ & 8 & $\$ 25,3$ & 101 & $\$ 481,3$ \\
1996 & 153 & $\$ 1774,6$ & 9 & $\$ 72,8$ & 162 & $\$ 1847,4$ \\
1997 & 184 & $\$ 3322,4$ & 25 & $\$ 1087,9$ & 205 & $\$ 3328,5$ \\
1998 & 144 & $\$ 2050,4$ & 10 & $\$ 218,1$ & 154 & $\$ 2268,5$ \\
Total & 878 & $\$ 14966,75$ & 93 & $\$ 1737,1$ & 971 & $\$ 16703,9$ \\
\hline \hline
\end{tabular}

Table 4

Distribution of IPO's by province. The sample consists of 971 Canadian IPOs by firms subsequently listed on the Toronto Stock Exchange, the Montreal Exchange, the Vancouver Exchange and the Alberta Exchange, from January 1991 through December 1998. **Others present the following provinces: Manitoba, Saskatchewan, Prince Edward's Islands, Newfoundland and Yukon. We included Junior Capital Pool IPOs.

\begin{tabular}{lcccccc}
\hline \hline \multicolumn{1}{c}{ Province } & $\begin{array}{c}\text { Common } \\
\text { shares } \\
\text { IPOs }\end{array}$ & $\begin{array}{c}\text { Gross proceed } \\
(\$ \text { millions })\end{array}$ & $\begin{array}{c}\text { Unit } \\
\text { IPOs }\end{array}$ & $\begin{array}{c}\text { Gross proceed } \\
(\$ \text { millions })\end{array}$ & $\begin{array}{c}\text { Full } \\
\text { sample }\end{array}$ & $\begin{array}{c}\text { Gross proceed } \\
(\$ \text { millions })\end{array}$ \\
\hline Alberta & 509 & $\$ 1390,14$ & 38 & $\$ 638,46$ & 547 & $\$ 2028,61$ \\
Ontario & 170 & $\$ 8148,26$ & 20 & $\$ 715,92$ & 190 & $\$ 8864,18$ \\
British Columbia & 127 & $\$ 1160,30$ & 17 & $\$ 57,94$ & 144 & $\$ 1218,24$ \\
Quebec & 48 & $\$ 2196,3$ & 4 & $\$ 85,2$ & 52 & $\$ 2281,5$ \\
Others** & 24 & $\$ 2071,73$ & 14 & $\$ 239,64$ & 38 & $\$ 2311,37$ \\
Total & 878 & $\$ 14966,75$ & 93 & $\$ 1737,17$ & 971 & $\$ 16703,9$ \\
\hline \hline
\end{tabular}


Table 5

Distribution of IPO's by industry. The sample consists of 971 Canadian IPOs by firms subsequently listed on the Toronto Stock Exchange, the Montreal Exchange, the Vancouver Exchange and the Alberta Exchange, from January 1991 through December 1998. **Others present the following sectors or industries: public services, transport, agriculture, conglomerates, film production and other.

\begin{tabular}{|c|c|c|c|c|c|c|}
\hline Industry or sector & $\begin{array}{c}\text { Common } \\
\text { shares } \\
\text { IPOs }\end{array}$ & $\begin{array}{c}\text { Gross proceed } \\
\text { (\$ millions) }\end{array}$ & Unit IPOs & $\begin{array}{c}\text { Gross proceed } \\
\text { (\$ millions) }\end{array}$ & $\begin{array}{c}\text { Full } \\
\text { sample }\end{array}$ & $\begin{array}{c}\text { Gross proceed } \\
\text { (\$ millions) }\end{array}$ \\
\hline Mining & 102 & $\$ 1644,1$ & 23 & $\$ 67,8$ & 125 & $\$ 1711,9$ \\
\hline Oil and gas & 54 & $\$ 1604,55$ & 23 & $\$ 90,44$ & 77 & $\$ 1695$ \\
\hline Production & 84 & $\$ 3927,98$ & & & 84 & $\$ 3927,9$ \\
\hline Technology & 86 & $\$ 2838,06$ & 12 & $\$ 28,39$ & 98 & $\$ 2866,45$ \\
\hline Financial services & 18 & $\$ 590,12$ & 6 & $\$ 682,17$ & 24 & $\$ 1272,3$ \\
\hline Real estate & 11 & $\$ 537,38$ & 4 & $\$ 398,23$ & 15 & $\$ 935,6$ \\
\hline $\begin{array}{l}\text { Biotech/ } \\
\text { pharmaceutical } \\
\text { products }\end{array}$ & 22 & $\$ 423,1$ & 2 & $\$ 50$ & 24 & $\$ 473,1$ \\
\hline $\begin{array}{l}\text { Communications } \\
\text { and media }\end{array}$ & 17 & $\$ 1254,38$ & 3 & $\$ 67,93$ & 20 & $\$ 1322,3$ \\
\hline Merchandising & 14 & $\$ 445,06$ & 13 & $\$ 333,03$ & 27 & $\$ 778,1$ \\
\hline Film production & 6 & $\$ 134,92$ & 2 & $\$ 3,61$ & 8 & $\$ 138,5$ \\
\hline $\begin{array}{l}\text { Others** (include } \\
\text { JCP) }\end{array}$ & $31+433$ & $\begin{array}{c}\$ 1258,08+\$ 30 \\
8,8\end{array}$ & 5 & $\$ 15,55$ & 469 & $\$ 1582,4$ \\
\hline Total & 878 & $\$ 14966,75$ & 93 & $\$ 1737,17$ & 971 & $\$ 16703,9$ \\
\hline
\end{tabular}




\section{Table 6}

Underpricing of Canadian IPOs. The sample consists of 971 Canadian IPOs by firms subsequently listed on the Toronto Stock Exchange, the Montreal Exchange, the Vancouver Exchange and the Alberta Exchange, from January 1991 through December 1998. We included Junior Capital Pool IPOs. The degree of underpricing is measured as following : UND (1) : (mean closing price of the five first days of listing- offer price)/ offer price, UND(2) : [(mean closing price of the five first days of listing - offer price)/ offer price] - [mean price of the TSE 300 index for the five days of listing - TSE 300 index price when offer price is fixed)/ TSE 300 index price when offer price is fixed]. ${ }^{\mathrm{P}}$ t-test for différences in average initial return between the following subgroups: ((common shares IPOs excluding JCP IPOs versus JCP IPO) and (common shares IPOs excluding JCP IPOs versus unit IPOs)) significant at $1 \%$ level. ${ }^{(\mathrm{N})}$ Kruskal-Wallis and Mann-Whitney t-tests for differences in average initial return between subsamples significant at $1 \%$ level.

\section{- UND(1) -}

\begin{tabular}{lccccc}
\hline \hline & $\begin{array}{c}\text { Common } \\
\text { shares IPOs } \\
\text { (exclude JCP) }\end{array}$ & JCP IPOs & $\begin{array}{c}\text { Common } \\
\text { shares IPOs } \\
\text { (include JCP) }\end{array}$ & Unit IPOs & Full sample \\
\hline Number & 445 & 433 & 878 & 93 & 971 \\
Mean & $20,57 \%$ & $135,41 \%{ }^{\mathrm{P}(\mathrm{N})}$ & $77,20 \%$ & $\left.40,06 \% \mathrm{P}^{\mathrm{P}}\right)$ & $73,65 \%$ \\
Standard error & 0,56 & 1,73 & 1,40 & 1,46 & 1,41 \\
Skewness & 2,15 & 3,66 & 4,29 & 3,66 & 4,17 \\
coefficient & & & & & \\
Kurtosis & 7,82 & 19,55 & 29,20 & 15,52 & 27,32 \\
coefficient & 7,65 & 16,21 & 16,25 & 2,63 & 16,2 \\
t- statistic & $5 \%$ & $100 \%$ & $30 \%$ & $1 \%$ & $30 \%$ \\
Median & & & & & \\
\hline \hline
\end{tabular}

\section{- UND(2) -}

\begin{tabular}{lccccc}
\hline \hline & $\begin{array}{c}\text { Common } \\
\text { shares IPOs } \\
\text { (exclude JCP) }\end{array}$ & JCP IPOs & $\begin{array}{c}\text { Common } \\
\text { shares IPOs } \\
\text { (include JCP) }\end{array}$ & Unit IPOs & Full sample \\
\hline Number & 445 & 433 & 878 & 93 & 971 \\
$\begin{array}{l}\text { Mean } \\
\text { Standard error }\end{array}$ & $22,11 \%$ & $140,88 \%{ }^{\mathrm{P}(\mathrm{N})}$ & $80,68 \%$ & $41,5 \%{ }^{\mathrm{P}(\mathrm{N})}$ & $76,93 \%$ \\
$\begin{array}{l}\text { Skewness } \\
\text { coefficient }\end{array}$ & 0,59 & 1,91 & 1,52 & 1,51 & 1,53 \\
$\begin{array}{l}\text { Kurtosis } \\
\text { coefficient }\end{array}$ & 2,39 & 4,78 & 4,29 & 3,72 & 5,29 \\
t- statistic & 8,76 & 37,43 & 53,73 & 16,47 & 49,83 \\
Median & 7,84 & 15,33 & 15,65 & 2,64 & 15,67 \\
\hline \hline
\end{tabular}




\section{Table 7}

Distribution of Canadian IPOs by year of issue. The sample consists of 971 Canadian IPOs by firms subsequently listed on the Toronto Stock Exchange, the Montreal Exchange, the Vancouver Exchange and the Alberta Exchange, from January 1991 through December 1998. We included Junior Capital Pool IPOs. The degree of underpricing is measured as following : UND (1) : (mean closing price of the five first days of listing- offer price)/ offer price, UND(2) : [(mean closing price of the five first days of listing offer price)/ offer price] - [mean price of the TSE 300 index for the five days of listing - TSE 300 index price when offer price is fixed)/ TSE 300 index price when offer price is fixed].

$*$ significant at $1 \%$ level ; ** significant at $5 \%$ level and *** significant at $10 \%$ level.

\begin{tabular}{|c|c|c|c|c|c|c|c|c|c|c|c|c|c|c|c|}
\hline \multirow[b]{2}{*}{ Year } & \multicolumn{3}{|c|}{$\begin{array}{c}\text { Common shares IPOs } \\
\text { without JCP }\end{array}$} & \multicolumn{3}{|c|}{ "JCP IPOs } & \multicolumn{3}{|c|}{$\begin{array}{c}\text { Common shares IPOs } \\
\text { with JCP }\end{array}$} & \multicolumn{3}{|c|}{ Unit IPOs } & \multicolumn{3}{|c|}{ Full sample } \\
\hline & Number & UND(1) & $\mathrm{UND}(2)$ & Number & UND(1) & $\mathrm{UND}(2)$ & Number & $\mathrm{UND}(1)$ & $\mathrm{UND}(2)$ & Number & UND(1) & $\mathrm{UND}(2)$ & Number & $\mathrm{UND}(1)$ & UND(2) \\
\hline 1991 & 11 & $-4,85 \%$ & $-5,26 \%$ & 2 & $0,55 \%$ & $2,24 \%$ & 13 & $-4,01 \%$ & $-4,11 \%$ & 6 & $34,29 \%$ & $41,19 \%$ & 19 & $8,07 \%$ & $10,19 \%$ \\
\hline 1992 & 25 & $31,72 \% * * *$ & $36,24 \% * * *$ & 8 & $85,42 \% * *$ & $86,98 \% * *$ & 33 & $44,74 \% *$ & $48,54 \% *$ & 5 & $-29,87 \%$ & $-29,93 \%$ & 38 & $34,92 \% * *$ & $38,21 \% * *$ \\
\hline 1993 & 78 & $15,87 \% * *$ & $16,52 \% *$ & 55 & $159,54 \% *$ & $178,17 \% *$ & 133 & $75,29 \% *$ & $83,37 \% *$ & 14 & $118,46 \%$ & $126,49 \%$ & 147 & $79,40 \% *$ & $87,48 \% *$ \\
\hline 1994 & 70 & $17,85 \% *$ & $17,19 \% *$ & 55 & $127,79 \% *$ & $139,65 \% *$ & 125 & $66,22 \% *$ & $71,07 \% *$ & 16 & $54,34 \%$ & $57,26 \%$ & 141 & $64,88 \% *$ & $69,50 \% *$ \\
\hline 1995 & 41 & $16,87 \% * *$ & $18,27 \% * *$ & 52 & $53,73 \% *$ & $58,63 \% *$ & 93 & $37,48 \% *$ & $40,83 \% *$ & 8 & $10,43 \%$ & $8,19 \%$ & 101 & $35,34 \% *$ & $38,25 \% *$ \\
\hline 1996 & 85 & $13,25 \% *$ & $14,33 \% *$ & 68 & $68,41 \% *$ & $76,02 \% *$ & 153 & $37,76 \% *$ & $41,75 \% *$ & 9 & $10,27 \%$ & $12,93 \%$ & 162 & $36,24 \% *$ & $40,15 \% *$ \\
\hline 1997 & 88 & $39,30 \% *$ & $45,13 \% *$ & 96 & $194,23 \% *$ & $194,98 \% *$ & 184 & $120,13 \% *$ & $123,31 \% *$ & 25 & $18,10 \%$ & $14,51 \%$ & 209 & $107,93 \% *$ & $110,30 \% *$ \\
\hline 1998 & 47 & $13,79 \% *$ & $11,94 \% *$ & 97 & $165,49 \% *$ & $163,73 \% *$ & 144 & $115,98 \% *$ & $114,19 \% *$ & 10 & $51,23 \%$ & $53,02 \%$ & 154 & $111,78 \% *$ & $110,22 \% *$ \\
\hline 1991-1998 & 445 & $20,57 \% *$ & $22,11 \% *$ & 433 & $135,41 \% *$ & $140,88 \% *$ & 878 & $77,20 \% *$ & $80,68 \% *$ & 93 & $40,59 \% *$ & $41,50 \% *$ & 971 & $73,64 \% *$ & $76,96 \% *$ \\
\hline
\end{tabular}




\section{Table 7 (cont'd)}

Distribution of Canadian IPOs by gross proceeds. The sample consists of 971 Canadian IPOs by firms subsequently listed on the Toronto Stock Exchange, the Montreal Exchange, the Vancouver Exchange and the Alberta Exchange, from January 1991 through December 1998. We included Junior Capital Pool IPOs. The degree of underpricing is measured as following: UND (1) : (mean closing price of the five first days of listing- offer price)/ offer price, $\mathrm{UND}(2)$ : [(mean closing price of the five first days of listing offer price)/ offer price] - [mean price of the TSE 300 index for the five days of listing - TSE 300 index price when offer price is fixed)/ TSE 300 index price when offer price is fixed].

- $\quad$ significant at $1 \%$ level; $* *$ significant at $5 \%$ level and *** significant at $10 \%$ level.

- $\quad{ }^{\mathrm{P}}$ t-test for differences in average initial return between the following subgroups : (Size $<1 \mathrm{M} \$$ and Size $\geq 20 \mathrm{M} \$$ ) significant at $1 \%$ level.

- ${ }^{(\mathrm{N})}$ Kruskal-Wallis and Mann-Whitney t-tests for differences in average initial return between the following subgroups (Size < $1 \$ M$ and Size $\geq 20 \$ M$ ) significant at $1 \%$ level.

\begin{tabular}{|c|c|c|c|c|c|c|c|c|c|}
\hline \multirow[b]{2}{*}{ Gross proceeds } & \multicolumn{3}{|c|}{ Common shares IPOs } & \multicolumn{3}{|c|}{ Unit IPOs } & \multicolumn{3}{|c|}{ Full sample } \\
\hline & Number & $\mathrm{UND}(1)$ & $\mathrm{UND}(2)$ & Number & $\mathrm{UND}(1)$ & $\mathrm{UND}(2)$ & Number & $\mathrm{UND}(1)$ & $\mathrm{UND}(2)$ \\
\hline Size $<1 \$ M$ & 540 & $119,07 \% *^{\mathrm{P}(\mathrm{N})}$ & $124,11 \% * \mathrm{P}(\mathrm{N})$ & 26 & $59,74 \% * * \mathrm{P}(\mathrm{N})$ & $63,94 \% * * \mathrm{P}(\mathrm{N})$ & 566 & $116,35 \% * \mathrm{P}(\mathrm{N})$ & $121,39 \% * \mathrm{~N}(\mathrm{~N})$ \\
\hline $1 \$ M \leq$ Size $<5 \$ M$ & 101 & $31,03 \% *$ & $32,94 \% *$ & 37 & $55,21 \% * *$ & $54,29 \% * *$ & 138 & $37,52 \% *$ & $38,67 \% *$ \\
\hline $5 \$ M \leq$ Size $<10 \$ M$ & 27 & $11,54 \% * * *$ & $11,22 \% * * *$ & 9 & $42,55 \% * *$ & $50,86 \% * *$ & 36 & $19,29 \% *$ & $21,13 \% *$ \\
\hline $10 \$ M \leq$ Size $<20 \$ M$ & 65 & $3,6 \%$ & $4,28 \%$ & 7 & $-25,7 \%$ & $-25,05 \%$ & 72 & $0,7 \% *$ & $1,4 \%$ \\
\hline Size $\geq 20 \$ M$ & 145 & $-1,36 \%$ & $-0,78 \%$ & 14 & $-5,25 \%$ & $-6,71 \%$ & 159 & $-1,7 \%$ & $-1,3 \%$ \\
\hline Total & 445 & $20,57 \% *$ & $22,11 \% *$ & 93 & $40,59 \% *$ & $41,50 \% *$ & 971 & $73,64 \% *$ & $76,96 \% *$ \\
\hline
\end{tabular}




\section{Table 7 (cont'd)}

Distribution of Canadian IPOs by sectors. The sample consists of 971 Canadian IPOs by firms subsequently listed on the Toronto Stock Exchange, the Montreal Exchange, the Vancouver Exchange and the Alberta Exchange, from January 1991 through December 1998. We included Junior Capital Pool IPOs. The degree of underpricing is measured as following : UND (1) : (mean closing price of the five first days of listing- offer price)/ offer price, UND(2) : [(mean closing price of the five first days of listing - offer price)/ offer price] - [mean price of the TSE 300 index for the five days of listing - TSE 300 index price when offer price is fixed)/ TSE 300 index price when offer price is fixed].

* significant at $1 \%$ level ; ** significant at $5 \%$ level and *** significant at $10 \%$ level.

\begin{tabular}{|c|c|c|c|c|c|c|c|c|c|}
\hline \multirow[b]{2}{*}{ Sector } & \multicolumn{3}{|c|}{ "Common shares IPOs } & \multicolumn{3}{|c|}{ Unit IPOs } & \multicolumn{3}{|c|}{ Full sample } \\
\hline & Number & $\mathrm{UND}(1)$ & $\mathrm{UND}(2)$ & Number & $\mathrm{UND}(1)$ & $\mathrm{UND}(2)$ & Number & $\mathrm{UND}(1)$ & $\mathrm{UND}(2)$ \\
\hline Biotechnology/ pharmaceutical products & 22 & $17,03 \%$ & $20,71 \%$ & 2 & $-18 \%$ & $-19 \%$ & 24 & $14,11 \%$ & $17,40 \%$ \\
\hline Communications and medias & 17 & $-4,66 \%$ & $-5,28 \%$ & 3 & $-49,7 \% * *$ & $-38,52 \%$ & 20 & $-11,42 \%$ & $-10,27 \%$ \\
\hline Financial services & 18 & $1,31 \%$ & $1,98 \%$ & 6 & $-22,33 \% *$ & $-24,74 \% *$ & 24 & $-4,59 \%$ & $-4,69 \%$ \\
\hline Film production & 6 & $4,05 \%$ & $-1,08 \%$ & 2 & $-8,33 \%$ & $-3,17 \%$ & 8 & $0,9 \% *$ & $-1,60 \%$ \\
\hline Merchandising & 14 & $-1,9 \%$ & $-1,2 \%$ & 13 & $41,10 \%$ & $38,38 \%$ & 27 & $18,80 \%$ & $17,82 \%$ \\
\hline Mining & 102 & $35,71 \% *$ & $38,75 \% *$ & 23 & $108,7 \% *$ & $113,5 \% *$ & 125 & $49,14 \% *$ & $52,50 \% *$ \\
\hline Oil and gas & 54 & $29,04 \% *$ & $34,20 \% *$ & 23 & $12,23 \%$ & $15,09 \%$ & 77 & $24,02 \% *$ & $28,49 \% *$ \\
\hline Production & 84 & $11,11 \% * *$ & $10,80 \% * *$ & & & & 84 & $11,11 \% * *$ & $10,80 \% * *$ \\
\hline Technology & 86 & $19,77 \% *$ & $21,08 \% *$ & 12 & $58,03 \%$ & $52,33 \%$ & 98 & $24,46 \% *$ & $24,91 \% *$ \\
\hline $\mathrm{JCP}$ & 433 & $135,41 \% *$ & $140,88 \% *$ & & & & 433 & $135,41 \% *$ & $140,88 \% *$ \\
\hline Real estate & 11 & $16,9 \%$ & $17,37 \%$ & 4 & $6,13 \%$ & $2,95 \%$ & 15 & $14,07 \%$ & $13,52 \%$ \\
\hline Others & 31 & $25,92 \% *$ & $34,20 \% *$ & 5 & $4,88 \%$ & $14,41 \%$ & 101 & $35,34 \% *$ & $38,25 \% *$ \\
\hline Total & 445 & $20,57 \% *$ & $22,11 \% *$ & 93 & $40,59 \% *$ & $41,50 \% *$ & 971 & $73,64 \% *$ & $76,96 \% *$ \\
\hline
\end{tabular}


Table 7 (cont'd). Distribution of Canadian IPOs by province, role of underwriters and market climate. The sample consists of 971 Canadian IPOs by firms subsequently listed on the Toronto Stock Exchange, the Montreal Exchange, the Vancouver Exchange and the Alberta Exchange, from January 1991 through December 1998. We included Junior Capital Pool IPOs. The degree of underpricing is measured as following : UND (1) : (mean closing price of the five first days of listing- offer price)/ offer price, $\operatorname{UND}(2)$ : [(mean closing price of the five first days of listing - offer price)/ offer price] - [mean price of the TSE 300 index for the five days of listing - TSE 300 index price when offer price is fixed)/ TSE 300 index price when offer price is fixed].

$*$ significant at $1 \%$ level ; ** significant at $5 \%$ level and $* * *$ significant at $10 \%$ level. ${ }^{\mathrm{P}}$ t-test for differences in average initial return between the following subgroups : (Ontario versus Alberta), (Ontario versus British Columbia (BC)), (Ontario versus Quebec), (high prestigious underwriters versus low prestigious underwriters) and (hot market versus cold market) significant at $1 \%$ level. ${ }^{(\mathrm{N})}$ Kruskal-Wallis and Mann-Whitney t-tests for differences in average initial return between the subgroups significant at $1 \%$ level.

\begin{tabular}{|c|c|c|c|c|c|c|c|c|c|c|c|c|c|c|c|}
\hline \multirow[b]{2}{*}{ Province } & \multicolumn{3}{|c|}{$\begin{array}{l}\text { Common shares IPOs } \\
\text { without JCP }\end{array}$} & \multicolumn{3}{|c|}{ JCP IPOs } & \multicolumn{3}{|c|}{$\begin{array}{c}\text { Common shares IPOs } \\
\text { with JCP }\end{array}$} & \multicolumn{3}{|c|}{ Unit IPOs } & \multicolumn{3}{|c|}{ Full sample } \\
\hline & $\mathrm{Nr}$ & $\mathrm{UND}(1)$ & $\mathrm{UND}(2)$ & $\mathrm{Nr}$ & UND(1) & $\mathrm{UND}(2)$ & $\mathrm{Nr}$ & $\mathrm{UND}(1)$ & $\mathrm{UND}(2)$ & $\mathrm{Nr}$ & UND(1) & UND(2) & $\mathrm{Nr}$ & UND(1) & $\mathrm{UND}(2)$ \\
\hline Alberta & 76 & $26,41 \% *^{* P(N)}$ & $27,94 \% *^{\mathrm{P}(\mathrm{N})}$ & 433 & $140,1 \% *$ & $145,1 \% *$ & 509 & $119,13 \% *$ & $124,01 \% *$ & 38 & $12,54 \%$ & $12,52 \%$ & 547 & $111,73 \% *^{\mathrm{P}(\mathrm{N})}$ & $116,27 \% * \mathrm{P}(\mathrm{N})$ \\
\hline $\mathrm{BC}$ & 127 & $35,95 \% * \mathrm{P}(\mathrm{N})$ & $39,88 \% *^{\mathrm{P}(\mathrm{N})}$ & & & & 127 & $35,95 \% *$ & $39,88 \% *$ & 17 & $106,83 \% * * *$ & $110,92 \% * * *$ & 144 & $44,32 \% * *^{\mathrm{P}(\mathrm{N})}$ & $48,26 \% * \mathrm{P}(\mathrm{N})$ \\
\hline Ontario & 170 & $11,20 \% *$ & $10,95 \% *$ & & & & 170 & $11,20 \% *$ & $10,95 \% *$ & 20 & $44,88 \%$ & $45,08 \%$ & 190 & $14,75 \% *$ & $14,55 \% *$ \\
\hline Quebec & 48 & $3,35 \% \%^{\mathrm{P}(10 \%)}$ & $5,37 \%$ & & & & 48 & $3,35 \%$ & $5,37 \%$ & 4 & $-9,33 \%$ & $-7,8 \%$ & 52 & $2,36 \%{ }^{\mathrm{P}(10 \%)}$ & $4,35 \%$ \\
\hline Others & 24 & $21,4 \% * * *$ & $22,14 \% * * *$ & & & & 24 & $21,40 \% * * *$ & $22,14 \% * * *$ & 14 & $40,88 \% * *$ & $44,83 \% * * *$ & 38 & $28,57 \% *$ & $30,50 \% *$ \\
\hline $\begin{array}{c}\text { High } \\
\text { prestigious } \\
\text { underwriters } \\
\text { Low } \\
\text { prestigious } \\
\text { underwriters }\end{array}$ & 229 & $9,37 \% * \mathrm{P}(\mathrm{N})$ & $10,39 \% *^{\mathrm{P}(\mathrm{N})}$ & 1261 & $27,81 \% * \mathrm{P}(\mathrm{N})$ & $128,53 \% *^{\mathrm{P}(\mathrm{N})}$ & 342 & $53,01 \% *^{\mathrm{P}(\mathrm{N})}$ & $20,02 \% *^{\mathrm{P}(\mathrm{N})}$ & 36 & $19,27 \% * \mathrm{P}(\mathrm{N})$ & $20,02 \% *^{\mathrm{P}(\mathrm{N})}$ & 378 & $49,79 \% * *^{\mathrm{P}(\mathrm{N})}$ & $50,67 \% *^{\mathrm{P}(\mathrm{N})}$ \\
\hline Hot market & 321 & $22,03 \% *$ & $23,93 \% *$ & 274 & $142,70 \% *$ & $150,98 \% *$ & 595 & $77,60 \% *$ & $82,43 \% *$ & 64 & $48,02 \% *$ & $49,47 \% *$ & 659 & $74,73 \% *$ & $79,23 \% *$ \\
\hline Cold market & 124 & $16,77 \% *$ & $17,41 \% *$ & 159 & $122,84 \% *$ & $123,46 \% *$ & 283 & $76,36 \% * *$ & $76,99 \% * *$ & 29 & $22,49 \%$ & $23,90 \%$ & 312 & $71,13 \% *$ & $72,06 \% *$ \\
\hline Total & 445 & $20,57 \% *$ & $22,11 \% *$ & 433 & $135,41 \% *$ & $140,88 \% *$ & 878 & $77,20 \% *$ & $80,68 \% *$ & 93 & $40,59 \% *$ & $41,50 \% *$ & 971 & $73,64 \% *$ & $76,96 \% *$ \\
\hline
\end{tabular}




\section{Table 8}

Results of multiple regressions. The regression model has the following form: $\mathrm{UND}_{\mathrm{i}}=\alpha_{0}+\alpha_{1} \mathrm{O}_{\mathrm{i}} \mathrm{G}_{\mathrm{i}}+\alpha_{2} \mathrm{MINING}_{\mathrm{i}}+\alpha_{3} \mathrm{~T}_{\mathrm{i}}+\alpha_{4} \mathrm{JCP}_{\mathrm{i}}$ $+\alpha_{5} \log (\text { Proceeds })_{i}+\alpha_{6} \mathrm{MM}_{\mathrm{i}}+\alpha_{7} \mathrm{PU}_{\mathrm{i}}+\varepsilon_{\mathrm{i}}$ where $\mathrm{UND}_{\mathrm{i}}$ is the degree of underpricing of the stock $\mathrm{i}$, O\&G takes a value of 1 for oil and gas issues and zero otherwise, MINING takes a value of 1 for mining issues and zero otherwise, $\mathrm{T}$ takes a value of 1 for technology issues and zero otherwise, JCP takes a value of 1 for junior capital pool issues and zero otherwise, MC is the market climate variable which takes a value of 1 for hot period and zero for cold period, PU takes a value of 1 for a participation of a prestigious underwriter in the IPO and 0 otherwise and Log denotes the natural logarithm. The proceed of the issue is used as a proxy for ex-ante uncertainty. The sample consists of 971 Canadian IPO's by firms subsequently listed on the Toronto Stock Exchange, the Montreal Exchange, the Vancouver Exchange and the Alberta Exchange, from January 1991 through December 1998. We included Junior Capital Pool IPOs. The degree of underpricing is measured as following : UND (1) : (mean closing price of the five first days of listing- offer price)/ offer price, UND(2) : [(mean closing price of the five first days of listing - offer price)/ offer price] - [mean price of the TSE 300 index for the five days of listing - TSE 300 index price when offer price is fixed)/ TSE 300 index price when offer price is fixed]. T-value are reported in parentheses. White's consistent covariance matrix is used in estimating standard errors and all t-values are reported on an adjusted basis.

*significant at $1 \%$ level, **significant at $5 \%$ level and ***significant at $10 \%$ level.

\begin{tabular}{|c|c|c|c|c|c|c|c|c|c|c|c|}
\hline & Constant & O\&G & $\mathrm{T}$ & MINING & $\mathrm{JCP}$ & $\begin{array}{c}\text { Log } \\
\text { (proceeds) }\end{array}$ & Market & PU & $\begin{array}{l}\text { Number } \\
\text { IPOs }\end{array}$ & $\begin{array}{c}\mathrm{R}^{2} \text { adjusted } \\
\mathrm{R}^{2}\end{array}$ & $\mathrm{~F}$ \\
\hline \multirow[t]{2}{*}{ UND(1) } & $1,86^{*}$ & 0,008 & 0,09 & 0,10 & $0,82 *$ & $-0,26^{*}$ & $0,16^{* * * *}$ & $-0,06$ & 971 & 0,1703 & 28,8 \\
\hline & $(3,71)$ & $(0,14)$ & $(0,60)$ & $(0,67)$ & $(5,45)$ & $(-3,63)$ & $(1,86)$ & $(-0,75)$ & & 0,1762 & \\
\hline \multirow[t]{2}{*}{ UND(2) } & $1,92 *$ & 0,008 & 0,09 & 0,12 & $0,86^{*}$ & $-0,27 *$ & $0,20 * *$ & $-0,09$ & 971 & 0,1587 & 27,1 \\
\hline & $(3,51)$ & $(0,04)$ & $(0,55)$ & $(0,71)$ & $(5,22)$ & $(-3,47)$ & $(2,16)$ & $(-0,98)$ & & 0,1648 & \\
\hline
\end{tabular}




\section{Liste des publications au CIRANO*}

Série Scientifique / Scientific Series (ISSN 1198-8177)

2001s-49 How Innovative Are Canadian Firms Compared to Some European Firms? A

Comparative Look at Innovation Surveys / Pierre Mohnen, Pierre Therrien

2001s-48 A Tale of Two Ports / Ngo Van Long et Kar-yiu Wong

2001s-47 Wage Policy of Firms: An Empirical Investigation / Stéphanie Lluis

2001s-46 Forecasting Some Low-Predictability Time Series Using Diffusion Indices / Marc

Brisson, Bryan Campbell et John W. Galbraith

2001s-45 The Importance of the Loss Function in Option Pricing / Peter Christoffersen et Kris Jacobs

2001s-44 Let's Get "Real" about Using Economic Data / Peter Christoffersen, Eric Ghysels et Norman R. Swanson

2001s-43 Fragmentation, Outsourcing and the Service Sector / Ngo Van Long, Ray

Riezman et Antoine Soubeyran

2001s-42 Nonlinear Features of Realized FX Volatility / John M. Maheu et Thomas H. McCurdy

2001s-41 Job Satisfaction and Quits: Theory and Evidence from the German

Socioeconomic Panel / Louis Lévy-Garboua, Claude Montmarquette et Véronique Simonnet

2001s-40 Logique et tests d'hypothèse : réflexions sur les problèmes mal posés en économétrie / Jean-Marie Dufour

2001s-39 Managing IT Outsourcing Risk: Lessons Learned / Benoit A. Aubert, Suzanne Rivard et Michel Patry

2001s-38 Organizational Design of R\&D Activities / Stefan Ambec et Michel Poitevin

2001s-37 Environmental Policy, Public Interest and Political Market / Georges A. Tanguay, Paul Lanoie et Jérôme Moreau

2001s-36 Wealth Distribution, Entrepreneurship and Intertemporal Trade / Sanjay Banerji et Ngo Van Long

2001s-35 Comparaison des politiques de rémunération en fonction des stratégies organisationnelles / Michel Tremblay et Denis Chênevert

2001s-34 Déterminants et efficacité des stratégies de rémunération : Une étude internationale des entreprises à forte intensité technologique / Michel Tremblay, Denis Chênevert et Bruno Sire

2001s-33 La multiplicité des ancres de carrière chez les ingénieurs québécois: impacts sur les cheminements et le succès de carrière / Yvon Martineau, Thierry Wils et Michel Tremblay

2001s-32 The Impact of Interface Quality on Trust in Web Retailers / Marie-Christine Roy, Olivier Dewit et Benoit A. Aubert

* Consultez la liste complète des publications du CIRANO et les publications elles-mêmes sur notre site Internet : 